\title{
New insight into the microtexture of chalks from NMR analysis
}

Faÿ-Gomord, Ophélie; Soete, Jeroen; Katika, Konstantina; Galaup, Serge; Caline, Bruno; Descamps, Fanny; Lasseur, Eric; Fabricius, Ida Lykke; Saïag, Jessica; Swennen, Rudy

Total number of authors:

11

Published in:

Marine and Petroleum Geology

Link to article, DOI:

10.1016/j.marpetgeo.2016.04.019

Publication date:

2016

Document Version

Peer reviewed version

Link back to DTU Orbit

\section{Citation (APA):}

Faÿ-Gomord, O., Soete, J., Katika, K., Galaup, S., Caline, B., Descamps, F., Lasseur, E., Fabricius, I. L., Saïag, J., Swennen, R., \& Vandycke, S. (2016). New insight into the microtexture of chalks from NMR analysis. Marine and Petroleum Geology, 75, 252-271. https://doi.org/10.1016/j.marpetgeo.2016.04.019

\section{General rights}

Copyright and moral rights for the publications made accessible in the public portal are retained by the authors and/or other copyright owners and it is a condition of accessing publications that users recognise and abide by the legal requirements associated with these rights.

- Users may download and print one copy of any publication from the public portal for the purpose of private study or research.

- You may not further distribute the material or use it for any profit-making activity or commercial gain

- You may freely distribute the URL identifying the publication in the public portal 


\section{Accepted Manuscript}

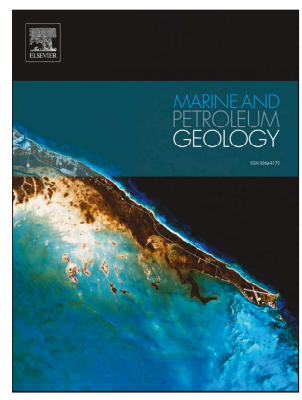

PII:

S0264-8172(16)30114-3

DOI:

10.1016/j.marpetgeo.2016.04.019

Reference: JMPG 2537

To appear in: Marine and Petroleum Geology

Received Date: 23 September 2015

Revised Date: 17 March 2016

Accepted Date: 20 April 2016

Please cite this article as: Faÿ-Gomord, O., Soete, J., Katika, K., Galaup, S., Caline, B., Descamps, F., Lasseur, E., Fabricius, I.L., Saïag, J., Swennen, R., Vandycke, S., New insight into the microtexture of chalks from NMR analysis, Marine and Petroleum Geology (2016), doi: 10.1016/ j.marpetgeo.2016.04.019.

This is a PDF file of an unedited manuscript that has been accepted for publication. As a service to our customers we are providing this early version of the manuscript. The manuscript will undergo copyediting, typesetting, and review of the resulting proof before it is published in its final form. Please note that during the production process errors may be discovered which could affect the content, and all legal disclaimers that apply to the journal pertain. 


\section{NEW INSIGHT INTO THE MICROTEXTURE OF CHALKS FROM NMR ANALYSIS}

Ophélie Faÿ-Gomord ${ }^{a^{*}}$, Jeroen Soete ${ }^{a}$, Konstantina Katika ${ }^{b}$, Serge Galaup ${ }^{c}$, Bruno Caline ${ }^{d}$, Fanny Descamps ${ }^{\mathrm{e}}$, Eric Lasseur ${ }^{\mathrm{f}}$; Ida Lykke Fabricius ${ }^{\mathrm{b}}$, Jessica Saïag ${ }^{\mathrm{g}}$, Rudy Swennen ${ }^{\text {a }}$, Sara Vandycke ${ }^{\mathrm{e}}$

a. KU Leuven, Geology, Department of Earth and Environmental Sciences, Celestijnenlaan 200E, 3001 Heverlee, Belgium

b. Technical University of Denmark, Civil Engineering Department, Brovej, Building 118, 2800 Kongens Lyngby, Denmark

c. EGID-Bordeaux 3, University Michel de Montaigne, 1, allée Daguin, 33607 Pessac Cedex, France

d. Total France E. \& P., avenue Larribau, 64018 Pau, France

e. UMONS, University of Mons, Faculty of Engineering, Mining Engineering Department, Place du parc 20, 7000 Mons, Belgium

f. BRGM, 3 avenue Claude Guillemin, BP 6009, 45060 Orléans Cedex 2, France

g. University Bourgogne Franche-Comté, UMR-CNRS 6282 Biogéosciences, 6 bd Gabriel, 21000 Dijon, France

*Ophelie.FayGomord@ees.kuleuven.be, Geology, KU Leuven, Belgium 


\section{ABSTRACT}

An integrated petrographical and petrophysical study was carried out on a set of 35 outcrop chalk samples, covering a wide range of lithologies and textures. In this study various chalk rock-types have been characterized, in terms of microtextures and porous network, by integrating both geological, sediment-petrological and petrophysical data, including porosity, permeability, low-field NMR (Nuclear Magnetic Resonance), MICP and specific surface area (BET) measurements. The data allow an in depth understanding of the NMR signal of chalks, with a focus on tight chalks, including all low reservoir quality chalks independently of their sedimentological and/or diagenetic history. The study aims to develop an NMR-based approach to characterize a broad range of chalk samples. The provided laboratory low-field NMR chalk classification can be used as a guide to interpret NMR logging data.

Based on the petrographical and petrophysical analysis, 6 groups of samples were identified, each of them characterized by a unique NMR signature : (1) micritic chalks, (2) grainy chalks, (3) cemented chalks, (4) marl-seam chalks, (5) argillaceous chalks and (6) silicified chalk. NMR $\mathrm{T}_{2}$ distributions were linked to pore body size and $\mathrm{T}_{2}$ logarithmic $\left(\mathrm{T}_{21 \mathrm{~m}}\right)$ was calculated. It is apparent that tight chalks, whether their characteristics are sedimentological or diagenetic, yield smaller pore body sizes $\left(\mathrm{T}_{21 \mathrm{~m}}<\right.$ $20 \mathrm{~ms}$ ), as well as narrower pore throats (average radius $<150 \mathrm{~nm}$ ) and lower permeability values (typically below $0.2 \mathrm{mD})$. Grainy chalks possess $T_{2}$ distributions reflecting larger pore sizes $\left(\mathrm{T}_{21 \mathrm{~m}}>60\right.$ $\mathrm{ms}$ ) and pore throats (average radius $>290 \mathrm{~nm}$ ) and higher permeabilities (up to $13 \mathrm{mD}$ ). The marlseam chalk samples yield bimodal $\mathrm{T}_{2}$ distributions, with a first peak related to the micritic matrix pores and a second peak related to intraparticle pores within fossils. For all samples, permeability was inferred from NMR spectra using SDR (Schlumberger Doll Research) model.

Keywords: NMR, chalk, petrography, petrophysics, microporosity, porecasts, marl-seams, MICP 


\section{INTRODUCTION}

Porous reservoir chalks have been thoroughly described and characterized in terms of petrography and petrophysics (Anderskouv \& Surlyk, 2011; Fabricius, 2003; Fabricius et al. 2007; Frykman, 2001; Hjuler \& Fabricius, 2009; Jakobsen et al., 2000; Lindgreen et al. 2010). Mallon \& Swarbrick, (2002, 2008) first focused on the large diversity of non-reservoir chalk lithologies that exhibit low permeabilities and suggested that these lithologies are present throughout much of the Chalk Group. According to the Joint Chalk Research group (Bailey et al., 1999), those non-reservoir or tight chalks include all chalks with matrix permeability lower than $0.2 \mathrm{mD}$, regardless of their origins. They became a focus of interest for petroleum industry since they might be underexplored reservoirs, or play a critical role in hydrocarbon migration, acting as seals or fluid conduits depending on their fracture patterns (Gennaro et al., 2013).

Recently, there has been a growing interest in the characterization of microtexture and pore network of microporous carbonate reservoirs (Brigaud et al., 2014; Cantrell and Hagerty, 1999; Deville de Periere et al., 2011; Kaczmarek et al., 2015; Lambert et al., 2006; Regnet et al., 2014; Richard et al., 2005; Vincent et al., 2011). Here, advanced techniques have been further developed and improved, including NMR, which gives detailed information about the porous network. The advantage of developing a NMR-based approach in chalk research is the application of NMR logging data, where NMR provides a continuous record of the pore size distribution in the reservoirs (Akbar et al., 1995, 2000; Fleury, 2000; Westphal et al., 2005). However, many effects affect the NMR signal such as pore coupling (Anand and Hirasaki, 2005) or surface relaxivity variation with mineralogy (Keating and Knight, 2012). These effects make the interpretation of NMR signals in carbonates a challenge, which was effectively addressed in a few studies (Brigaud et al., 2014; Vincent et al., 2011; Yousef et al., 2011).

NMR signals have been investigated in reservoir chalk pore networks; (Li et al., 2014; Megawati et al., 2012; Nurmi \& Standen, 1997), but tight chalks have been disregarded to some extent. In order to enable the use of NMR logging for chalk rock-typing, this study aims to explain the NMR signal of a wide range of outcrop chalk samples, including tight chalks, based on petrographical observations and petrophysical measurements. Chalk samples were selected from North-West European outcrops and include chalks from various depositional settings, and exhibiting various diagenetic histories. As a result, a broad spectrum of mineralogies, degrees of cementation, compaction and sedimentary textures, and therefore a large spectrum of chalk petrophysical properties is covered in this study. Relationships are established between porosity, permeability, MICP, petrography and SEM observations, in order to determine the geological characteristics which constrain the NMR response. 


\section{MATERIAL AND METHODS}

\subsection{Sampling}

In the field thirty-five core samples, $10 \mathrm{~cm}$ diameter by $30 \mathrm{~cm}$ long, were drilled from representative outcrops that reflect various sedimentological, tectonic and diagenetic histories, resulting in chalks displaying a wide range of lithologies, reservoir properties and petrographical textures. The samples were collected from 15 different locations spread on 6 study areas across Belgium, England and France (Table 1). The petrographical and petrophysical properties of each sample are the combined result of its sedimentological setting and a set of diagenetic modifications. This study focuses on the petrophysical and petrographic characteristics of the chalk lithologies rather than on the processes which led to the current reservoir properties.

Upper Cretaceous chalk samples ranging from the Cenomanian to Campanian were studied. Sedimentological features impacting the microtexture and petrophysical properties of chalks include insoluble residue content (e.g. Fabricius \& Borre, 2007; Røgen \& Fabricius, 2002; Strand et al., 2007), size and shape of chalk particles (e.g. Neugebauer, 1974, 1975) and the mode of deposition (e.g. Damholt \& Surlyk, 2004; Scholle et al., 1998). In addition to these sedimentological features, diagenesis is controlled by local tectonics (e.g. Hancock, 1975; Jones et al., 1984; Mimran, 1975, 1978), the pore water chemistry (e.g. Fabricius \& Borre, 2007) and burial setting. The latter, which includes the burial temperature, stress and pressure at a given depth, is a parameter with major impact on the diagenesis, that primarily governs the overall porosity reduction and thus strongly impacts the rock properties and textural characteristics (e.g. Borre \& Fabricius, 1998; Fabricius, 2003; Scholle, 1974, 1977). Therefore outcrops with maximum burial paleodepths ranging from $200 \mathrm{~m}$ in Harmignies Quarry, Mons (Dupuis and Vandycke, 1989) to $1800 \mathrm{~m}$ in Flamborough Head, Yorkshire, UK (Menpes and Hillis, 1996) were selected (Figure 1).

\subsection{Petrography}

The homogeneity of the core samples was verified with X-ray CT scanning, using a Siemens somatom scanner with a resolution of $0.2 \mathrm{~mm}$. Heterogeneous features like marl-seams, bioturbations or veins were not avoided while making plugs, since they are representative elements of the samples. In the laboratory, plugs $(2.5 \mathrm{~cm}$ diameter by $5 \mathrm{~cm}$ long) were cored. Petrophysical and petrographical analyses were performed on the same plug whenever possible, or at least on nearby material.

Macroscopic samples were described using the classification established by Fritsen et al. (1996) who characterized 18 chalk lithotypes. Fritsen et al. (1996) modified Dunham's classification to make it suitable for application by the unaided eye. This means that the maximum mud particle size of 20 microns, as defined by Dunham (1962) or Lucia, (1995) could not be maintained. Several wackestone - observed as wackestones in thin-section - were classified as mudstones macroscopically. 
For this study, 21 standard $30 \mu \mathrm{m}$-thick thin-sections were prepared. The sediment texture was described based on Dunham's (1962) classification of limestones, using a natural light microscope. JMicroVision Image analysis (Roduit, 2007) was performed on natural light thin-section images in order to quantify the proportion of grains $(>20 \mu \mathrm{m})$ present in the micritic matrix. Thin-sections were impregnated under vacuum conditions with a fluorescence epoxy resin to highlight the porous network. The pores recognizable by optical microscopy essentially correspond to intraparticle mesoporosity (Fabricius et al., 2008; Nurmi \& Standen, 1997) since micropores are too small to be identified under the optical microscope. Image analysis, performed on fluorescence light thin-section images provides a quantification of this mesoporosity.

Scanning Electron Microscopy (SEM) on fresh surfaces of the samples was used to observe noncarbonate minerals, to identify microporosity and to study microtextural features. Investigations were carried out on an EM XL30 FEG field emission microscope equipped with an energy dispersive spectrometer (EDS) with image magnifications from 1000 to 20000 times. Classifications based on the morphology of the micritic matrix have been developed for microcrystalline calcite (Deville de Periere et al., 2011; Kaczmarek et al., 2015; Lambert et al., 2006). If nano-bioclasts were sometimes observed among these microcrystalline calcites; they however never exceeded $5 \%$ of the sediment volume. The proposed classifications are therefore not applicable to chalk samples, and a detailed descriptive chalk microtextures classification needed to be developed. Throughout this paper, the term microtexture describes the texture of the chalk matrix, as observed under SEM; while texture always refers to the Dunham sedimentary texture classification.

In the frame of this study, a chalk diagenesis index was defined based on SEM observations. The diagenesis index ranks the samples on a scale from 0 to 10 , with zero $(0)$ being the uncemented chalk and ten (10) being the completely cemented chalk. Seven criteria are used to quantify the degree of diagenesis from SEM observation. They include parameters used for the classical micrite classification such as (1) the micritic matrix texture, grading from microrhombic to anhedral compact or (2) the grain contact from punctic to coalescent. Other parameters, more specific to chalks are (3) the disintegration of coccoliths, (4) coccolith grain overgrowths, (5) large cemented zones, (6) authigenic cement crystals and (7) intraparticle cementation, which is observed also in thin-section with fluorescence light. Each criterion was rated from 0 (uncemented) to 10 (completely cemented) and the average of those criteria provides the diagenesis index.

SEM was also used to scan and investigate porecast surfaces. Porecasts were obtained by dissolving $30 \mu \mathrm{m}$-thick thin-sections impregnated with epoxy-resin in a 10M hydrochloric acid solution, for 3 hours (Beckett and Sellwood, 1991). The study of porecasts is a helpful technique to visualize and evaluate the shape and distribution of the pore network. 
Acid-insoluble residues of the samples were obtained by dissolving roughly crushed samples of chalk in $2 \mathrm{M}$ hydrochloric acid followed by washing of the residue with deionized water (Hjuler and Fabricius, 2009).

\subsection{Petrophysics}

\subsubsection{Porosity and Permeability}

The porosity was determined by direct measurement of grain volume and bulk volume. The grain volume was determined by helium expansion in a Boyle's Law EPS Porosimeter. The gas permeability of the samples was determined with a Vinci nitrogen permeameter. The plugs were mounted in a "Hassler" type core holder at a confining pressure of 400 psi and a steady state gas flow was established through the samples. The permeabilities were corrected for gas-slippage using Klinkenberg's empirical correlation.

\subsubsection{Nuclear Magnetic Resonnance (NMR)}

The principles of the NMR method are described in detail by Grunewald \& Knight (2009), Kenyon (1997) and Vincent et al. (2011). NMR is a powerful tool to characterize the pore size distribution, based on the magnetization decay of fluid molecules. NMR measurements consist of aligning the hydrogen nuclei (proton) with static and oscillating magnetic fields and then measuring the relaxation time after the removal of the magnetic field. The NMR relaxation response of a single fluid filled pore can be expressed by the exponential decay of the transverse magnetization signal, called $1 / T_{2} . T_{2}$ is a characteristic time that represents the magnetic decay of the protons within the fluid after their polarization. The $\mathrm{T}_{2}$ time of a single fluid filled pore is proportional to the volume to surface ratio (V/S) of the pore, and therefore, to the pore body size according to equation 1 (Coates et al., 1999).

$$
\left.1 / \mathrm{T}_{2}=1 / \mathrm{T}_{2(\mathrm{~b})}+\rho(\mathrm{S} / \mathrm{V}) \quad \text { (Equation } 1\right)
$$

with $T_{2}: T_{2}$ surface relaxation time, $T_{2(b)}$ : bulk $T_{2}$ surface relaxation time, $\rho: T_{2}$ relaxing strength of the grain surface, $S$ : surface area of the pore and V: volume of the pore.

The $T_{2}$ relaxation time distribution of all pores in a rock sample may be considered equivalent to the pore body-size distribution of the rock, although tortuosity and pore shape also strongly impact the $\mathrm{T}_{2}$ distribution (Kenyon, 1997).

As part of this study, laboratory measurements were performed on 35 fully water-saturated 1 inch-plug samples, with a GeoSpec2 NMR Core Analyzer at $2.25 \mathrm{MHz}$, in a temperature controlled chamber at $35^{\circ} \mathrm{C}$ and atmospheric pressure. $\mathrm{T}_{2}$ relaxations were measured using the Carr-Purcel-Meiboom-Gill (CPMG) pulse sequences (Dunn et al., 2002). The polarization time was selected at $5 \mathrm{~s}$, number of echoes at 16000 , and the echo spacing (TE) at of $100 \mu \mathrm{s}$. The $\mathrm{T}_{2}$ relaxation spectra were generated using the WinDXP (Oxford Instruments, UK) software. All measurements were conducted at high 
Signal to Noise Ratio (SNR>200) in order to increase the reliability of the results. For a detailed description of the analytical methods, the readers should refer to Katika et al., 2014.

\subsubsection{Mercury-Injection Capillary Pressure (MICP)}

Mercury-injection capillary pressure (MICP) tests allow the measurement of the distribution of the pore throat radii. The technique, first described by Purcell (1949) and subsequantly by Wardlaw \& Taylor (1976) is based on the principle that mercury is a near-perfect non-wetting liquid, that will only infiltrate the rock pores when force is applied. Spaces with larger pore throats are saturated at low pressure, but mercury progressively invades pores with smaller pore throats as pressure is step-by-step increased up to 30,000 psi. When a sufficiently high pressure is reached, the entire connected pore system, representing even the smallest pore throats, will be completely saturated. The pore throat radii distribution is calculated from the mercury capillary pressure curves by means of the Young Laplace's mechanical equilibrium equation. Measurements were performed on a selection of 21 samples, with a Micromeritics Autopore IV device whose accuracy ranges from $3.5 \mathrm{~nm}$ to $0.5 \mathrm{~mm}$ pore throat radii.

\subsubsection{Specific surface (BET)}

BET-analysis (Sing et al., 1985) on 8 carefully selected samples was carried out to get a better insight into the specific surface of peculiar samples. Analyses were performed with a Micromeritics ASAP 2020 instrument. BET-analysis provides specific surface area evaluation by nitrogen multilayer adsorption measured as a function of relative pressure. The technique encompasses external area and pore area evaluations to determine the total specific surface area in $\mathrm{m}^{2} / \mathrm{g}$ yielding important information on the sample microtexture. In this study, the technique was used in order to estimate the specific surface area, and its impact on the NMR $\mathrm{T}_{2}$ response was considered. 


\section{RESULTS}

Based on the integration of both petrographical observations and NMR measurements, 6 chalk lithotypes were defined: (1) micritic chalk, (2) grainy chalk, (3) cemented chalk, (4) argillaceous chalk, (5) marl-seam chalk, and (6) silicified chalk (see overview of petrographical and petrophysical results in Error! Reference source not found. and Error! Reference source not found.).

\subsection{Petrography}

Cores have been sampled with carefully avoiding the obviously weathered zones, affected by cryogenic weathering or by meteoric water circulation (e.g. around fractures, damaged zones etc.). Duperret et al. (2005) showed that salt-weathering may affect the first centimeters of the seashore cliff outcrops. However, computerized tomography of the 30-cm long core samples showed no variations in density within each sample, reflecting no differential weathering. In addition, SEM observation of the 35 samples showed no presence of precipitation related to meteoric diagenesis as described by Hjuler and Fabricius (2009), and very rare halite crystals precipitations within sea-shore samples. Hence, in this study, the impact of surface diagenesis is considered as minor.

\subsubsection{Micritic chalk}

Micritic chalks were named based on their mud-dominated texture, often mudstone, occasionally wackestone, according to Dunham's (1962) classification (Error! Reference source not found. and Table 2). Macroscopically, micritic chalk is a pure (less than $1 \%$ insoluble residue) chalk mudstone, which is not strongly indurated. CT scanning showed that micritic chalks are also very homogeneous samples. Thin-section observations showed mostly the presence of mudstone fabrics, where grains are mostly planktonic foraminifera which constitute only 1 to $6 \%$ of the samples based on image analysis. These mudstone facies form in deep offshore depositional environments, with low hydrodynamics and particles settling in the water column (Lasseur et al., 2009). SEM observations clearly show that the main components of the rock are very well preserved coccolith fragments. The fragments gave rise to a microrhombic matrix texture, with rare authigenic calcite crystals. Contacts between coccolith fragments are mostly punctic and the interparticle porosity is well preserved. The diagenesis index of micritic chalk was determined under SEM and fluoresence light microscopy ranged from 0 to 2, indicative of uncemented to poorly cemented samples. SEM observation of resin porecasts show that pores form a well-connected network of spherical pores. High magnification SEM-photographs of the outer edges of a foraminifera test show the very fine connections between the intraparticle porosity and the surrounding matrix pores.

\subsubsection{Grainy chalk}


Grainy chalk samples are grain-dominated and possess a packstone texture. Macroscopically, grainy chalks cannot always be easily distinguished from micritic chalks, as they also appear similar to low strength pure chalks. They often appear white, homogeneous and according to the classification of Fritsen et al. (1996) most of them qualify as mudstone in terms of macroscopic texture. Only one coarse lag facies sample infilling the base contourite channelized structures on the Normandy cliffs (Lasseur, 2007) can be classified as grainy chalk with the naked eye. The other grainy chalk samples were characterized as such based on microscopic observations. In thin-section, those chalks show a higher foraminiferal and bioclastic content which, as described by Nurmi \& Standen (1997), gives rise to a packstone texture (Dunham, 1962), with 32 to $43 \%$ of grains occurring in a micritic matrix. Under SEM, the micritic matrix of grainy chalks is rather similar to the micritic chalk matrix. The diagenesis is equally low ranging from 1 to 2.

\subsubsection{Cemented chalk}

The cemented chalk lithotypes include chalk samples cemented during either eodiagenesis or mesodiagenesis. All cemented chalk samples are macroscopically characterized by their high strength, which either comes from early cementation in hardgrounds, burial diagenesis or a combination of both. In thin-section, cemented chalks display a mudstone texture, with 5 to $8 \%$ grains, which are (mostly forams or calcispheres), which are either cemented with large sparite crystals of several dozen micrometers or micritized. Although they rank as Dunham's mudstones, the sedimentological origin of cemented chalk deposits varies widely. SEM suggests that cementation obliterates sedimentological differences among the cemented chalk samples. All cemented chalks exhibit similar microtextures with coalescent grain contacts, many authigenic calcite crystals and grain overgrowths. Microtextural differences were rarely encountered between early cemented chalks and stylolitized chalks, cemented through deep burial diagenesis (e.g. Flamborough Head samples). Deeply buried chalks show a higher disintegration of coccoliths and seemingly more grain overgrowths than early cemented chalks. Cemented chalk resin porecasts indicate a porous network with straight-edged pores under SEM, generated by the euhedral crystal faces of calcite rhombodedra. Pore throats also appear very narrow and void zones of $>10 \mu \mathrm{m}$ in the porecast reflect large grain aggregates, cemented together, completely filling the pores. Overall, the diagenesis index values of cemented chalks range from 6 to 7.

\subsubsection{Marl-seam chalk}

Marl-seam structures have been observed and described in chalk since Weiler (1957), and are commonly described as common pressure solution features, resulting from burial diagenesis (Lind, 1993), although a strict sedimentary origin is still considered by some authors (Wray \& Jeans, 2014). According to Jennings \& Mazzullo (1986), the minimal burial depth required to form marl-seams in chalk is $400 \mathrm{~m}$. Marl-seam samples are often associated with a pseudo-nodular fabric and the thickness 
and geometry of the marl-seams depend on the initial chalk lithology as well as the intensity of the pressure solution processes.

Although marl-seams may preferentially initiate in a layer with a slightly higher initial clay-content, field observations show that marl-seams form essentially in homogeneous chalks with low insoluble residue $(<5 \%)$. Marl-seams are not observed in chalks with high insoluble residue $(>10 \%)$, nor in chalks with regular chert nodule bands nor in hardgrounds. Computerized tomography analysis revealed that marl-seams density is higher than surrounding chalk (Figure 5). Microscopic observations reveal that marl-seam chalks possess a mudstone - wackestone texture, with a percentage of grains ranging from 6 to $17 \%$. Fluorescence microscopy highlights the presence of intraparticle pores, inside calcispheres, foraminifera and other bioclasts.

SEM observations of marl-seam chalks show a wide range of microtextures, which relate to the intensity of the burial pressure solution or the initial sedimentary clay-content. However, sampling is also critical because of the heterogeneity of the samples. For example the microtexture observed inside marl-seams is significantly different from the surrounding chalk. The sampling of marl-seams for insoluble residue measurements also strongly influences the measurements, which range from 2 to $15 \%$. Unlike other chalk lithotypes, there is not one typical texture that allows to identify marl-seam chalks. If the sampling is made in the clay-rich seams, then the microtexture is dominated by the clay flakes, which may show a preferential orientation if the sampling is made a few millimeters away from the clay-seams, the texture is not dominated by the clay-content and microtextural features includes authigenic cement crystals and grain overgrowths that do not develop in the clay-rich seams.

\subsubsection{Argillaceous Chalk}

Argillaceous chalk samples come from Cap-Blanc Nez, (Boulonnais, France) and Eastbourne (Sussex, England) and are of early Cenomanian age. The argillaceous facies is clearly identifiable macroscopically by its light to dark grey color. Burrowings are very common, often from Zoophycos and Chondrites (Amédro \& Robaszynski, 2001). However, computerized tomography revealed an homogeneous density within the samples (Figure 5). The insoluble residue content of argillaceous chalks ranges from $10 \%$ to $30 \%$ and is mostly detrial, including clays (illite, smectite, glauconite or kaolinite), quartz and a small amount of pyrite. One sample from Cap Blanc Nez (OF/CB10, Table 2) shows lower insoluble residue because it had been affected by early diagenesis, characterized by an extensive burrowing. Early calcite cementation likely reduced the relative abundance of insoluble residue. The Cenomanian coincides with the beginning of a major transgression leading to the formation of the Chalk sea. The detrital input was still high then, whereas the biological carbonate production from coccolithophorids was probably moderate. The shift from dominance of detrital input to carbonate production lead to the sedimentation of argillaceous chalks, with petrographic characteristics somewhere in between marls and chalk. 
Thin-section observations showed that clays are dispersed in the brownish matrix. The texture of argillaceous chalk varies from mudstone to wackestone, where grains mostly include foraminifera, bioclasts and calcisphere, representing between 7 and 18\% from thin-section image analysis. However, argillaceous chalk are clearly recognizable by their microtexture under the SEM. Clay flakes are dispersed in the matrix, and under the mechanical compaction stress they tend to align parallel to the bedding, as described by Mallon \& Swarbick (2008). The texture of the matrix appears more compact in argillaceous chalk than in micritic chalk, because of the poor sorting. In contrast, pure micritic chalks likely develop a more solid framework by crystal overgrowth cementation during diagenesis, so they better withstand mechanical compaction. Because of the dispersed clay flakes in the matrix, contacts between coccolith fragments are reduced and argillaceous chalks develop very low grain-tograin contact dissolution or grain overgrowths. Thus, even if they are initially more affected by mechanical compaction, chemical compaction is lower than in clay-free chalks. In the determination of the diagenesis index, criteria such as crystal overgrowths or coalescence of grain contacts are very low, while the overall micritic texture and the coccolith disintegration are significantly higher than in micritic chalks. The diagenesis index values range from 3.5 to 5 for argillaceous chalk and slightly higher, with values up to 6 , for chalks having undergone early cementation, such as firmgrounds.

\subsubsection{Silicified Chalk}

Silicified chalks are not often encountered in chalk outcrops, where silica is mostly present under the form of chert nodules. Silicified chalks have been previously described in the Ekofisk and South Arne oil fields in the North Sea (Jakobsen et al., 2000; Lindgreen et al., 2010; Gennaro et al., 2013). The only studied silicified outcrop chalk sample in this study comes from Brunneval, in Normandy (France). In the field, this silicified chalk appears as a $30 \mathrm{~cm}$ thick bed and displays a clear silicification front. The light-grey silicified rock still possesses a chalk texture with distinct bioclasts, but the induration of the rock is higher than the surrounding chalk. The insoluble residue quantity of this sample reaches $76 \%$.

Fluorescence microscopy revealed zones of varying porosity. In each of these zones, the initial chalk texture was preserved with bioclast and calcisphere outlines still distinguishable. In the higher porosity zone, patches of amorphous silica occur; while in the lower porosity zone, which appears completely silicified, chalcedony can be observed in what used to be the chalk-matrix.

SEM micrographs from thin-sections show that silica is dispersed in the chalk matrix but is developed as a cement in foraminifera and calcisphere chambers (Error! Reference source not found.). Furthermore, SEM observations of rock chips indicate that the silica is present as both chalcedony aggregates and as subhedral to euhedral quartz crystals (Figure 6). The precipitation of nano-quartz has been interpreted as a consequence of the supersaturation of $\mathrm{SiO}_{2}$ in pore water (Jakobsen et al., 2000; Fröhlich, 2007; Lindgreen et al., 2010), related to increased silica concentrations, most probably 
resulting from the dissolution of biogenic silica (i.e. radiolaria, diatoms and silicoflagellates). However, this proposed direct precipitation of quartz is highly controversial because studies based on X-ray diffraction and SEM-based petrography indicate that biogenic silica dissolves and reprecipitates as opal-CT, which after sufficient time and temperature transforms into quartz (Kastner 1981). The nano-size of the resulting quartz aggregates mimics that of Opal-CT lepispheres (Hjuler and Fabricius 2009).

\subsection{Petrophysics}

\subsubsection{Porosity and Permeability}

Petrophysically, chalk is defined as a mineralogically pure, highly porous and low permeability carbonate rock. Among selected outcrop samples, micritic chalk ranges from 30 to $45 \%$ porosity and 2 to $6 \mathrm{mD}$ permeability and grainy chalk shows similar values with porosity ranging from 30 to $45 \%$, and permeability from 3 to $13 \mathrm{mD}$. The atypical, highly-permeable sample of $13 \mathrm{mD}$ permeability (OF/ETR33, Table 3) is a grainstone-textured bioclastic chalk from Etretat (France).

However, not all chalks are porous, nor can they all be considered pure carbonate. Some chalks show exceptionally low permeability values (Mallon and Swarbrick, 2008, 2002; Gennaro et al., 2013), which will strongly affect the overall reservoir properties. The Joint Chalk Research (JCR, http://jointchalkresearch.org/) has termed those low reservoir chalks as "tight chalks", which are characterized by a matrix permeability below $0.2 \mathrm{mD}$. In the studied samples, all the argillaceous chalks, the deeply-buried cemented chalk from Flamborough Head (England, samples OF/FA15, OF/FA39 and OF/FA11), the nodular marl-seam chalk from Cap Blanc Nez (OF/CB16) and the silicified chalk (OF/BR01) samples qualify as tight chalks, because of their very low permeability values (Error! Reference source not found.). As mentioned before, marl-seam exhibit variations in the intensity of compaction. That results in porosity variations from 14 to $40 \%$ and permeability from 0.19 to $2.7 \mathrm{mD}$. The cemented chalks from Cap Blanc Nez (OF/CB14) and Normandy (OF/SC01) show higher porosity and permeability, which may be explained by the lower maximum burial paleodepth, not exceeding $500 \mathrm{~m}$. The determination coefficient $\left(\mathrm{R}^{2}\right)$ between porosity and permeability values for all studied samples equals 0.78 (Error! Reference source not found.A).

\subsubsection{MICP}

Many case studies used MICP to define micropores, mesopores and macropores in carbonates based on the pore throat radius (PTR) (Bousquié, 1979; Frank et al., 2005; Goni et al., 1968; Skalinski \& Kenter, 2015). Each study proposed its own cut-off values to define micropores, ranging from a PTR lower than 30nm (Goni et al., 1968) to lower than $250 \mathrm{~nm}$ (Frank et al., 2005). For the studied chalk samples, PTRs range from 12 to $550 \mathrm{~nm}$ (Error! Reference source not found.). Measurements show an average PTR of $255 \mathrm{~nm}$ for micritic chalks and $380 \mathrm{~nm}$ for grainy chalks. The actual PTRs of pores 
in micritic chalks and grainy chalks overlap since sedimentary texture and NMR measurements were used to differentiate between chalk lithotypes. Due to overgrowths and formation of euhedral calcite crystals, PTRs in cemented chalk are reduced to an average of $120 \mathrm{~nm}$. The reduced pore throat size of cemented chalk can be clearly understood and visualized with the epoxy resin pore-casts (Error! Reference source not found.). Argillaceous chalks are characterized by an average PTR of $50 \mathrm{~nm}$, with pore throats size reduced by the presence of thin clay flakes in the pore throats. The smallest average PTR $(12 \mathrm{~nm})$ is observed in the silicified chalk sample. In the marl-seam chalks PTRs measurements range from 50 to $215 \mathrm{~nm}$, depending on the compaction intensity and on the microtexture of the chalk before the initiation of burial diagenesis.

The pore throat radii distribution is unimodal and normally distributed for micritic, cemented and silicified chalk, suggesting that one family of pore throats controls mercury intrusion into the studied samples. Pore throat radii distributions of argillaceous chalks are unimodal with a significant shoulder towards low values, also observed in some marl-seam samples. Pore throat distributions of grainy chalk samples OF/CM06 and OF/SS01 are unimodal and symmetrical, but OF/ETR33 (Error! Reference source not found.) displays a bimodal pore throat distribution with one dominant peak $(0.1-5 \mu \mathrm{m})$ with a shoulder towards high values and a small broad peak at high values $(10-100 \mu \mathrm{m})$, which may result from a second family of pore throats, related to the larger amount of coarser grains in the samples, accompanied by inter- and intra-particle porosity.

\subsubsection{BET measurements}

The specific surface of 8 representative samples ( 2 micritic chalks, 1 grainy chalk, 2 cemented chalks, 2 marl-seam chalks, 1 argillaceous chalk) was measured. The specific surface of micritic chalk samples was measured at $2.2 \mathrm{~m}^{2} / \mathrm{g}$, which similar to the data reported by Røgen \& Fabricius (2002), stating that the specific surface area of chalk biogenic calcite is on average $2 \mathrm{~m}^{2} / \mathrm{g}$. The latter authors also state that the specific surface area is mostly controlled by carbonate content and mineralogy of the non-carbonate fraction and that the specific surface area of quartz is about $5 \mathrm{~m}^{2} / \mathrm{g}$, that of kaolinite about $15 \mathrm{~m}^{2} / \mathrm{g}$ and that of smectite about $60 \mathrm{~m}^{2} / \mathrm{g}$. The high specific surface areas for the noncarbonate mineralogies explain the higher values measured for argillaceous chalk (OF/CB11) and marl-seam chalk (OF/CB13 \& OF/CB16), respectively $11.23 \mathrm{~m}^{2} / \mathrm{g}$ and $8.6 \mathrm{~m}^{2} / \mathrm{g}$ (Error! Reference source not found.). For the examined chalk samples, this is consistent with the clay flakes dispersed in the matrix that were observed with SEM. The specific surface of cemented chalk equals $1.9 \mathrm{~m}^{2} / \mathrm{g}$ for the Flamborough Head deeply-buried chalk sample (OF/FA39) and $2.7 \mathrm{~m}^{2} / \mathrm{g}$ for the Cap Blanc Nez (France) firmground sample (OF/CB14). Based on the insoluble residue amounts of respectively 3.5\% and $5.9 \%$ of the latter samples, higher specific surfaces were expected. Overgrowth cement precipitation on the surface of the grains however smoothed the particles and reduced the specific surface area (Borre \& Fabricius, 1998; Olsen et al., 2008), which is well illustrated by the porecasts 
(Error! Reference source not found., B). The impact of cementation and insoluble residue counteract each other, resulting in specific surface area values similar to micritic chalks. The lowest specific surface area $\left(0.8 \mathrm{~m}^{2} / \mathrm{g}\right)$ was measured on an atypical grainstone-textured chalk sample (OF/ETR33) and is coherent with presence of coarser grains.

\subsubsection{Low-field NMR}

The $\mathrm{T}_{2}$ distribution reflects a distribution of V/S ratios, which includes the pore shape factor as well as the surface rugosity. The high specific surface provided by clays in argillaceous or marl-seam chalk therefore tends to decrease the average $T_{2}$ time. The logarithmic mean of the $T_{2}$ distribution $\left(T_{21 \mathrm{~m}}\right)$ was calculated for each sample from the unimodal $T_{2}$ time distribution. The average $T_{21 m}$ value equals 47 $\mathrm{ms}$ for micritic chalks and $81 \mathrm{~ms}$ for grainy chalks. As expected, the average $\mathrm{T}_{2 \mathrm{~lm}}$ of argillaceous chalk (5 ms) is significantly lower, because the dispersed clay flakes in the micritic matrix both effectively reduce the pore volume and increase the specific surface area so that $T_{2}$ time decreases. The low value of $\mathrm{T}_{2 \mathrm{~m}}$ in cemented chalks ( $16 \mathrm{~ms}$ ) relates to the pore size reduction due to cementation.

Sediment deposition in strong hydrodynamic environments results in coarser chalk, characterized by a packstone texture and larger pores. Both factors lead to higher $T_{21 m}$ values in NMR. The OF/ETR33 sample displays a bimodal MICP distribution, which might reflect the presence of a second family of pore throats, related to larger grains. This second family of pores is confirmed by a bimodal $\mathrm{T}_{2}$ distribution in NMR with a second peak towards higher $\mathrm{T}_{2}$ values (800-3000 ms) and is in agreement with thin-section observations showing large inter- and intraparticle pores related to large sponges or bryozoa fragments.

Marl-seam chalks often show unimodal MICP patterns (Error! Reference source not found.A) while in NMR clear bimodal $\mathrm{T}_{2}$ distributions are observed (Error! Reference source not found.B). The clayrich seams and the clean chalk layers in marl-seam chalks are both part of the highest peak of the NMR-T $T_{2}$ distribution, which is referred to as matrix porosity. The concentration of clay flakes in the matrix, along preferential seams, locally reduces pore size and thus also $T_{2}$ values but they do not isolate the pores from the surrounding cemented and clay-free matrix, resulting in a homogeneous first peak signal in NMR, referred to as matrix peak. Based on petrographical observations, the high- $\mathrm{T}_{2}$ value lowest peak of the NMR signal is related to the high intraparticle porosity featured in marlseams layers. The unimodal MICP signal can be explained by the fact that the scattered and isolated intraparticle pores are only accessible through narrow pore throats in the foraminifera tests (Error! Reference source not found.C). On the contrary, due to the large difference in pore size between matrix porosity and intraparticle porosity and because of a weak coupling-effect, the NMR signature is slightly bimodal. The $\mathrm{T}_{2 \mathrm{~m}}$ of bimodal marl-seam chalk samples have been calculated for the first mode of the $T_{2}$ distribution only and therefore reflects the log mean of the matrix porous network, excluding 
the intraparticle pores. A relationship between the insoluble residue content and the $T_{21 m}$ value is visible for the marl-seam samples (Error! Reference source not found.D), and shows that pressuresolution results in higher clay concentration and lower $\mathrm{T}_{21 \mathrm{~m}}$ values.

\section{DISCUSSION}

Following a detailed and integrated analysis of available petrophysical and petrographical data, it appears that NMR $\mathrm{T}_{2}$ distribution provides invaluable information about chalk porous network. Five lithotypes can be directly inferred from low-field NMR $T_{2}$ distributions and the permeability of each sample can be assessed. The NMR signature records key-information about chalk microtexture that results from both sedimentological and diagenetic history.

\subsection{Marl-seam samples}

Marl-seam samples stand out from other chalk lithologies by their wide range of petrographic and petrophysical properties. The microtexture of marl-seam chalk is by far the most complex because of the initial intrinsic heterogeneities and pressure dissolution intensity that affect the characteristics of each sample. This lithotype is formed by alternating poorly cemented clay-rich seams and clean chalk intervals whose pores are more cemented and therefore a wide range of microtextures and pore features are observed. Despite these heterogeneities, all marl-seam chalk samples have one common characteristic: a bimodal NMR $\mathrm{T}_{2}$ distribution (Error! Reference source not found.).

The $T_{2}$ values of the first peak have a range that falls between typical values for argillaceous and clean chalks (5-100 ms), while the second peak is on the coarser side of chalk $\mathrm{T}_{2}$ distributions ( $>100 \mathrm{~ms}$ ). It was tempting to attribute the first NMR-peak to clay rich-seams and the second to clean chalk. However, the integration of NMR measurements with petrographical observations led to the conclusion that the second mode of porosity is in fact related to the well-preserved intraparticle porosity in those samples (see 3.2.4, Error! Reference source not found.). All the matrix pores were therefore registered in one single broad peak, which might be inferred to their very good connectivity and possibly a pore coupling effect. The preservation of the intraparticle porosity in marl-seam layers is interpreted as resulting from a diagenetic shielding effect related to the presence of the clays. The shielding effect induced by clay flakes also reduces the grain to grain contacts and subsequently decrease dissolution processes, inhibiting calcite cementation.

Westphal (2006) described the differential diagenesis in marl-seams with calcium-carbonate export from the marl-seam layers and import in the pure layers. In this study, marl-seams layers (OF/CB13, $\mathrm{OF} / \mathrm{SC} 02, \mathrm{OF} / \mathrm{SC} 03)$ are often found in between cemented chalk layers (OF/CB14, OF/SC01) with especially low percentages or completely lacking intraparticle porosity, while cementation is low to nonexistent in marl-seams layers, potentially because of a shielding effect. Note that this shielding 
effect may have been of influence already before the formation of marl-seams caused by burial diagenesis. While marl-seams initiation may be sedimentologically-controlled, and generated on bedding-parallel inhomogeneities; their atypical bimodal NMR signal is likely the result of a differential diagenesis. The unique bimodal signal of marl-seams is likely related to interparticle porosity preservation, because marl-seams layers provide calcium carbonate to the system by pressuresolution processes without in-situ cementation; and fluids saturated in calcium-carbonate will preferentially circulate and precipitate in pure chalk layers.

\subsection{The peculiar silicified chalk}

NMR and MICP signals of each NMR-unimodal chalk lithotype are compared (Error! Reference source not found.) and the micritic, grainy, cemented and argillaceous chalks have unique $T_{2}$ distributions. Only the silicified chalk sample (OF/BR01) overlaps with the cemented chalks. Pore throat sizes of the silicified chalk sample are, however, lower than any other lithotype and yield very low permeability $(0.04 \mathrm{mD})$. Pore throat size and permeability are seemingly more reduced by silicification than pore volume and overall porosity $(26.4 \%)$. The nanometer-sized silica particles, which are dispersed in the matrix, probably obstruct pore-throat accesses, while neither drastically reducing pore volumes. Silicified chalk beds occur as centimeter-thick layers, and may act as intrareservoir seals (Gennaro et al, 2013; Jakobsen et al., 2000; Lindgreen et al., 2010; 2012). NMRlogging in oil-field will not be sufficient to discriminate between cemented chalk and the silicified layers, but an integrated study with gamma-ray logging and/or SEM cutting observations will normally allow to identify them.

\subsection{Rock typing from NMR}

The overview of this integrated petrographical and petrophysical catalog of chalks shows how sedimentary setting and burial history impact the chalk properties, affect their microtextures and thus play a crucial role in shaping the NMR signal. The main parameters specifically controlling chalk microtextures and hence $T_{2}$ distributions are (1) the primary grain size, (2) the non-carbonate content, and (3) the degree of cementation.

Non-carbonate constituents and cements are the two key factors altering chalk reservoir properties, by reducing porosity and permeability. Thin clay flakes surrounding the grains as well as pore-filling authigenic crystals or grain-overgrowth cementation reduce both the pore throat and pore-body sizes (Figure 12). However, they may sometimes counteract each other, as for example when high detritic clay content prevents cementation during burial diagenesis.

Vincent et al. (2011) proposed a cut-off value between micro- and mesoporosity at a $\mathrm{T}_{2}$ time of $200 \mathrm{~ms}$ in neritic marine carbonates. This threshold is not sufficient to distinguish the different pore types that 
were observed in chalk samples. Based on the cut-off of the above mentioned authors, all samples in this study, except the grainy chalk, would be interpreted as $100 \%$ microporous. Therefore, new cut-off values were defined to separate three classes of pores in the studied chalk samples. The cut-off for chalk-microporosity was defined based on the micritic chalk samples, whose unimodal peak always plots between $T_{2}=25 \mathrm{~ms}$ and $T_{2}=100 \mathrm{~ms}$. This $T_{2}$ interval defines the chalk microporosity. All values below $\mathrm{T}_{2}=25 \mathrm{~ms}$ were defined as chalk-nanoporosity, and values above $100 \mathrm{~ms}$ as chalkmesoporosity.

The observed lithotypes plot in clearly separate areas based on the relative abundance of these porosity classes (Figure 13). In this diagram, the various chalk lithotypes that were previously described clearly stand out. The porous network of grainy chalks is made up of chalk-microporosity in the mud-matrix fraction and mesoporosity in the grain-fraction of the sediment. The micritic matrix porosity of marlseam chalks ranges between the chalk-nanoporous and microporous poles, depending on the claycontent and degree of cementation in each sample. The second mode of the bimodal $\mathrm{T}_{2}$ distribution materializes in the diagram by a shift of the pore class percentages towards the chalk-mesoporosity pole.

Chalk-nanoporosity is mostly represented in the cemented and clay-rich chalks, where the pore size is reduced. Nevertheless, the extremely low $\mathrm{T}_{2}$ values of argillaceous chalks also reflects the increased specific surface due to clays, and the small amount of pyrite that was observed in argillaceous chalk also has a reducing effect on the $\mathrm{T}_{2}$ time. However, the good correspondence between MICP and NMR responses (Error! Reference source not found.) validates the coherence of the acquired NMR responses.

To go further, uniaxial compressive strength has been measured on the studied samples and clear distinct behavior appeared for each NMR-determined chalk lithotype (Descamps et al., 2015), opening the prospect of predicting some geomechanical properties from NMR measurements.

\subsection{Permeability estimation from NMR}

Rock permeability can be estimated if the pore throat size distribution is known. Because the combined results of MICP and NMR in this study showed that pore throat and NMR pore body size are related, with a determination coefficient of $\mathrm{R}^{2}=0.88$ (Error! Reference source not found.B, C), permeability can thus be inferred from NMR measurements in chalks (Minh et al., 1997).

The applicability of the Schlumberger-Doll-Research (SDR) model (Kenyon et al., 1988), used to calculate permeability from NMR measurements, was tested on studied chalk samples. In the $\mathrm{K}_{\mathrm{SDR}}$ model, the permeability is predicted from the sample porosity $(\varnothing)$ and $T_{2 l m}$ (Eq. 2). The calibration constant ' $a$ ' was determined graphically from the gradient of the best fit curve to the data in the 
$\mathrm{T}_{2}(\mathrm{~lm})^{2} \phi^{4}$ versus permeability plot (Error! Reference source not found.A) and equals 0.09 . SDR relationships in carbonates are expected to yield low values for 'a' (Minh et al., 1997). Furthermore, smaller pores generally contain much more surface area and higher surface area to volume ratios, which results in shorter surface relaxation times according to Equation 1 (Coates et al., 1999). The absence of macropores in the chalk samples results in a low value for the calibration constant ' $a$ '.

$\mathrm{K}_{\mathrm{SDR}}=\mathrm{a}\left(\mathrm{T}_{2 \mathrm{~lm}}\right)^{2} \phi^{4}$

(Equation 2)

with $\varnothing$ : porosity, a: calibration constant, $T_{2}(s)$ : $T_{2}$ surface relaxation time, $\rho: T_{2}$ relaxing strength of the grain surface, $\mathrm{S}$ : surface area of the pore and $\mathrm{V}$ : volume of the pore.

The pore-coupling phenomenon which may occur in grainy chalk directly impacts the $T_{2 l m}$ average of the $T_{2}$ distribution and is a key parameter for calculating the permeability from NMR data in the SDR model (Equation 1). Despite this potential inaccuracy, the SDR modelled permeability is in rather good agreement with measured core permeabilities. The relation between both permeability is described in equation 3 and yields a determination coefficient of 0.85 (Error! Reference source not found.B).

$\mathrm{K}_{\text {core }}=1.2266 . \mathrm{K}_{\mathrm{SDR}}^{0.5034}$

(Equation 3)

Knowing that the NMR based SDR permeability model is applicable to chalk, permeability can potentially be estimated from NMR well logging based on this calibration (Equation 3). However, it is important to remember that $T_{2}$ is sensitive to temperature. Indeed, physical processes such as the relaxation of the bulk fluid molecules, the molecules interaction with the surface, or the molecules diffusion between pores, could be affected by borehole temperature (Freedman, 2006). The latter processes depend on the rock properties and can result in an increase, decrease or null $\mathrm{T}_{2}$ shift with temperature. NMR data should be corrected for temperature affects to reduce uncertainty in NMRestimated permeabilities used in reservoir models. 


\section{CONCLUSION}

On the basis of 35 chalk outcrop samples, covering a wide range of sedimentary facies, burial histories and petrophysical properties, this study provides keys for the interpretation of low-field NMR analyses, with regards to petrographical and petrophysical characteristics of chalks.

The main conclusions are :

(1) Low-field NMR $T_{2}$ distributions allow 5 chalk lithotypes to be differentiated on the basis of their pore sizes and shapes: micritic, grainy, cemented, argillaceous and marl-seam chalks. Chalk NMR signals are mainly constrained by three parameters: the depositional grain size, the non-carbonate content and the degree of cementation. In more detail, we observed that:

- in micritic chalks, clean and highly porous mudstones made essentially of poorly cemented coccolith fragments, $\mathrm{T}_{21 \mathrm{~m}}$ values range from 40 to $60 \mathrm{~ms}$.

- in argillaceous chalks, the high clay content results in a higher specific surface area and thus lower $\mathrm{T}_{2}$ values, with $\mathrm{T}_{2 \mathrm{~m}}$ ranging from 3 to $10 \mathrm{~ms}$.

- in cemented chalks, cementation reduces pore size volumes and thus $T_{2}$ values, with $\mathrm{T}_{21 \mathrm{~m}}$ ranging from 15 to $18 \mathrm{~ms}$.

- in grainy chalks, characterized by a packstone texture and low cementation, NMR-T distribution reflects the coarse porosity related to the high bioclastic fraction (foraminifera, echinoderms, bryozoan, etc.)

- in marl-seam chalks, the NMR signature is characterized by a bimodal $\mathrm{T}_{2}$ distribution. The main peak probably represents the pores of the matrix, whether or not they contain clays, while the second peak, with higher $\mathrm{T}_{2}$ values most likely reflect the intraparticle porosity.

(2) The preservation of intraparticle porosity in marl-seam chalks likely stem from a shielding effect caused by clays. Marl-seam chalks therefore may act as fluid barriers and the intermixed clay-free chalk behave as preferential fluid pathways. These diagenetic features therefore should be taken into account to understand the pore-collapse mechanisms occurring in some North Sea oil fields.

(3) Tight chalks or low reservoir quality chalks encompass different lithotypes. The main permeability-reducing factors are: (1) the non-carbonate content, related to sedimentological settings (e.g. argillaceous chalks) and burial diagenesis (e.g. marl-seam chalks); (2) the degree of cementation, either eogenetic (e.g. hardgrounds) and relating to the depositional setting or mesogenetic and resulting from chemical compaction. Those parameters strongly modify chalk microtexture and reduce pore-throat and pore body sizes, altering permeability.

(4) Permeability can be inferred from low-field NMR measurements using the SDR (Schlumberger Doll Research) model. 
(5) By applying the proposed NMR-based chalk classification, a continuous record of the pore size and chalk microtexture characteristics in the hydrocarbon reservoirs can be obtained.

NMR, together with MICP and SEM observations, provides detailed and holistic information about chalk pore networks, and a good insight into the chalk microtexture. NMR well logging, especially if combined with observations on cuttings should allow an accurate prediction of the petrological and petrophysical characteristics of chalks in wells. NMR is again proving to be a powerful tool for the analysis of pore networks, allowing the discrimination of lithotypes even in chalks. 
6. ACKNOWLEDGEMENTS

This study has been funded by TOTAL SA, as part of a "Fractured Tight Chalk" project, including the $\mathrm{PhD}$ of Mrs Ophélie Faÿ-Gomord. Our thanks goes to Yves Leroy, TOTAL, project leader for the support he granted us throughout this study. We are thankful to DREAL Nord Pas de Calais and the Fortress of Mimoyecques for their sampling authorizations in protected areas, as well as CBR cement for the opportunity to work and sample in the Harmignies quarry (Belgium). We would also like to thank Herman Nijs (KU Leuven), for the preparation of the thin-sections and his smart input in the making of porecasts, and Evy Vereecken (KU Leuven) for her help and guidance during the MICP measurements. We also thank Pierre-Yves Collin (University of Burgundy) and Jean-Pierre Sizun (University of Besançon) for the sampling of certain outcrops in Haute-Normandy (France). We are very grateful to Pierre Van Landschoot (UMONS) for his help during different steps of sample preparation, as to Francis Amédro (University of Burgundy) for his help and useful advice during fieldwork in Cap Blanc Nez (France). Finally, many thanks to Franciszek J. Hasiuk and Axel Munnecke for their constructive reviews which led to significant improvement of the manuscript. 


\section{REFERENCES}

Akbar, M., Petricola, M., Watfa, M., Badri, M., Charara, M., Boyd, A., Cassel, B., Nurmi, R., Delhomme, J.P., Grace, M., Kenyon, B., Roestenburg, J., 1995. Classic interpretation problems: evaluating carbonates. Oilf. Rev. 7, 38-57.

Amédro Francis \& Robaszynski Francis, 2000. Les craies à silex du Turonien supérieur au Santonien du Boulonnais (France) au regard de la stratigraphie événementielle. Comparaison avec le Kent (U.K.), Géologie de la France, 4, p. 39-56.

Amédro, F., Robaszynski, F., 2001. Les craies cénomaniennes du Cap Blanc-Nez (France) au regard de la stratigraphie évènementielle. Extension géographique de niveaux repères du bassin angloparisien (Boulonnais, Kent, Normandie) à l'Allemagne du Nord. Bull. Trimest. la société géologique Normandie Amis Muséum du Havre 87, 9-29.

Anand, V., Hirasaki, J., 2005. Diffusional coupling between micro and macroporosity for NMR relaxation in sandstones and grainstones., in: Proceedings of SPWLA 46th Annual Logging Symposium, June 26-29, New Orleans, LA.

Anderskouv, K., Surlyk, F., 2011. Upper Cretaceous chalk facies and depositional history recorded in the Mona-1 core, Mona Ridge, Danish North Sea, Geological Survey of Denmark and Greenland Bulletin, 25, 1-60.

Bailey, H., Gallagher, L., Hampton, M., Krabbe, M., Jones, B., Jutson, D., Moe, A., Nielsen, E.B., Petersen, N.W., Riis, F., Sawyer, D., Sellwood, B.W., Strand, T., Overli, P., Oxnevad, I., 1999. Joint Chalk Research Phase V: A Joint Chalk Stratigraphic Framework. Norwegian Petroleum Directorate (NPD), Stavanger.

Beckett, D., Sellwood, B.W., 1991. A simple method for producing high-quality porecasts of carbonate rocks. Sediment. Geol. 71, 1-4. doi:10.1016/0037-0738(91)90002-U

Borre, M., Fabricius, I.L., 1998. Chemical and mechanical processes during burial diagenesis of chalk: An interpretation based on specific surface data of deep-sea sediments. Sedimentology 45, 755 769. doi:10.1046/j.1365-3091.1998.00178.x

Boulvain, F. and Pingot, J-L., 2012. Genèse du sous-sol de la Wallonie. Classe des Sciences, Académie royale de Belgique, 190 pp.

Bousquié, P., 1979. Texture and porosity of carbonate rocks, $\mathrm{PhD}$ thesis. University of Paris IV. 
Brigaud, B., Vincent, B., Durlet, C., Deconinck, J.F., Jobard, E., Pickard, N., Yven, B., Landrein, P., 2014. Characterization and origin of permeability-porosity heterogeneity in shallow-marine carbonates: From core scale to 3D reservoir dimension (Middle Jurassic, Paris Basin, France). Mar. Pet. Geol. 57, 631-651. doi:10.1016/j.marpetgeo.2014.07.004

Bristow, R., Mortimore, R.N.,Wood, C.J.,1997. Lithostratigraphy for mapping the Chalk of southern England. Proceedings of the Geologist's Association 108, 293-315.

Cantrell, D.L., Hagerty, R.M., 1999. Microporosity in arab formation carbonates, Saudi Arabia. GeoArabia 4, 129-154.

Coates, G.R., Hardwick, R.C.A., Roberts, D., 1999. The magnetic imaging log characterised by comparaison with petrophysical properties and laboratory core data: Paper 22723, in: Proceedings of the Society of Petroleum Engineers 66th Annual Technical Conference and Exhibition. p. 4.

Damholt, T., Surlyk, F., 2004. Laminated-bioturbated cycles in Maastrichtian chalk of the North Sea: oxygenation fluctuations within the Milankovitch frequency band. Sedimentology 51, 13231342. doi:10.1111/j.1365-3091.2004.00672.x

Descamps, F., Faÿ, O., Vandycke, S., VanLandschoot, P., Leroy, Y., Caline, B., Schroeder, C., Swennen, R., Tshibangu, J.-P., 2015. Relations between lithology and geomechanical properties of chalks from NW Europe, in: The Geology of Geomechanics, The Geological Society. London.

Deville de Periere, M., Durlet, C., Vennin, E., Lambert, L., Bourillot, R., Caline, B., Poli, E., 2011. Morphometry of micrite particles in cretaceous microporous limestones of the middle east: Influence on reservoir properties. Mar. Pet. Geol. 28, 1727-1750. doi:10.1016/j.marpetgeo.2011.05.002

Dunham, R.J., 1962. Classification of carbonate rocks according to depositional texture. Mem. Amer. Assoc. Pet. Geol. 1, 108-121.

Dunn, K.J., Bergman, D.J., Latorraca, G.A., 2002. Nuclear Magnetic Resonance Petrophysical and Logging Applications.

Dupuis, C., Vandycke, S., 1989. Tectonique et karstification profonde: un modèle de subsidence original pour le Bassin de Mons. Ann. Soc. Géol. Belgique 112, 479-487. 
Fabricius, I.L., 2003. How burial diagenesis of chalk sediments controls sonic velocity and porosity. Am. Assoc. Pet. Geol. Bull. 87, 1755-1778.

Fabricius, I.L., Borre, M.K., 2007. Stylolites, porosity, depositional texture, and silicates in chalk facies sediments. Ontong Java Plateau - Gorm and Tyra fields, North Sea. Sedimentology 54, 183-205. doi:10.1111/j.1365-3091.2006.00828.x

Fabricius, I.L., Gommesen, L., Krogsbøll, A., Olsen, D., 2008. Chalk porosity and sonic velocity versus burial depth: Influence of fluid pressure, hydrocarbons, and mineralogy. Am. Assoc. Pet. Geol. Bull. 92, 201-223. doi:10.1306/10170707077

Fabricius, I.L., Røgen, B., Gommesen, L., 2007. How depositional texture and diagenesis control petrophysical and elastic properties of samples from five North Sea chalk fields. Pet. Geosci. 13 , 81-95. doi:10.1144/1354-079306-707

Fleury, M., 2000. The use of NMR in petrophysics- from physical principles to applications. London Petrophys. Soc. DiaLog 8, 1-2 (online).

Frank, S., Narayanan, R., Hansen, P.M., Allen, D., Albrechtsee, T., Steinhardt, H., Raven, M., Fordham, E., Bize, E., Rose, D., 2005. Carbonate rock typing using NMR data: a case study from Al Shaheen field, offshore Qatar, in: International Petroleum Technology Conference, Doha , 2123 November.

Freedman, R., 2006. Advances in NMR Logging. Soc. Pet. Eng. 58, 60-66. doi:10.2118/89177-JPT

Fritsen, A., Crabtree, B., Mandzuich, K., Moe, A., Rasmussen, F., Siemers, T., Soiland, G., Tirsgaard, H., 1996. Description and Classification of Chalks: North Sea Central Graben, Joint Chalk Research Phase IV. Norwegian Petroleum Directorate.

Fröhlich, F., 2007. Deep-sea biogenic silica: new structural and analytical data from infrared analysis geological implications. Terra Nov. 1, 267-273. doi:10.1111/j.1365-3121.1989.tb00368

Frykman, P., 2001. Spatial variability in petrophysical properties in Upper Maastrichtian chalk outcrops at Stevns Klint, Denmark. Mar. Pet. Geol. 18, 1041-1062.

Gale, AS, Kennedy, WJ, Voigt, S et al., (2005). Stratigraphy of the Upper Cenomanian-Lower Turonian Chalk succession at Eastbourne, Sussex, UK: Ammonites, inoceramid bivalves and stable carbon isotopes. Cretaceous Research, 26 (3), 460-487. 
Gennaro, M., Wonham, J.P., Sælen, G., Walgenwitz, F., Caline, B., Faÿ-Gomord, O., 2013. Characterization of dense zones within the Danian chalks of the Ekofisk Field, Norwegian North Sea. Pet. Geosci. 19, 39-64.

Goni, I., Ragot, J.P., Sima, A., 1968. Méthode d'étude du champ microfissural des minéraux et des roches et possibilités d'applications en géologie. Bull. BRGM 4, 51-92.

Gräfe, K.-U., 1999. Foraminiferal evidence for Cenomanian sequence stratigraphy and palaeoceanography of the Boulonnais (Paris Basin, N-France): Palaeogeography, Palaeoclimatology, Palaeoecology, v. 153, p. 41-70.

Grunewald, E., Knight, R., 2009. A laboratory study of NMR relaxation times and pore coupling in heterogeneous media. Geophysics 74, E215-E221. doi:10.1190/1.3223712

Hancock, J.M., 1975. The petrology of the Chalk. Proc. Geol. Assoc. 86, 499-535. doi:10.1016/S0016-7878(75)80061-7

Hjuler, M.L., Fabricius, I.L., 2009. Engineering properties of chalk related to diagenetic variations of Upper Cretaceous onshore and offshore chalk in the North Sea area. J. Pet. Sci. Eng. 68, 151170. doi:10.1016/j.petrol.2009.06.005

Jakobsen, F., Lindgreen, H., Springer, N., 2000. Precipitation and flocculation of spherical nano-silica in North Sea chalk. Clay Miner. 35, 175-175. doi:10.1180/000985500546567

Jennings, R.H., Mazzullo, J.M., 1986. Shallow Burial Diagenesis of Chalks and Related Sediments at Site 550 on the Goban Spur. Geol. Soc. Am. South-Central Sect. 17th Annu. Meet. Geol. Soc. Am. (GSA), Boulder, CO, United States 15, 40-41.

Jones, M.E., Bedford, J., Clayton, C., 1984. On natural deformation mechanisms in the Chalk. J. Geol. Soc. 141 , 675-683. doi:10.1144/gsjgs.141.4.0675

Juignet, P., Breton, G., 1994. Stratigraphie, rythmes sédimentaires et eustatismes dans les craies turoniennes de la région de Fécamp (Seine-Maritime, France); expression et signification des rythmes de la craie. Bulletin trimestriel de la Société géologique de Normandie et des Amis du Muséum du Havre 81, 55-81.

Kaczmarek, S.E., Fullmer, S.M., Hasiuk, F.J., 2015. A universal classification scheme for the microcrystals that host limestone microporosity. J. Sediment. Res. 85, 1197-1212. doi:10.2110/jsr.2015.79 
Katika, K., Adassi, M., Alam, M.M., Fabricius, I.L., 2014. Changes in Specific Surface as observed by NMR, caused by saturation of Chalk with porewater bearing divalent Ions. Diffus. Fundam. 22, $1-14$.

Keating, K., Knight, R., 2012. The effect of spatial variation in surface relaxivity on nuclear magnetic resonance relaxation rates. Geophys. 77 , E365-E377. doi:10.1190/geo2011-0462.1

Kennedy, W.J. (1969) The correlation of the Lower Chalk of south-east England. the Geologists' Association, 80, 459-560.

Kenyon, W.E., 1997. Petrophysical Principles of Applications of NMR Logging. Soc. Petrophysicists Well-Log Anal. 38.

Kenyon, W.E., Day, P.I., Straley, C., Willemsen, J.F., 1988. A three-part study of NMR longitudinal relaxation properties of water-saturated sandstones. SPE Form. Eval. 3, 622-636.

Lambert, L., Durlet, C., Loreau, J.P., Marnier, G., 2006. Burial dissolution of micrite in Middle East carbonate reservoirs (Jurassic-Cretaceous): Keys for recognition and timing. Mar. Pet. Geol. 23, 79-92. doi:10.1016/j.marpetgeo.2005.04.003

Lasseur, E., 2007. La Craie du Bassin de Paris (Cénomanien-Campanien, Crétacé supérieur). Sédimentologie de faciès, stratigraphie séquentielle et géométrie 3D. 435.

Lasseur, E., Guillocheau, F., Robin, C., Hanot, F., Vaslet, D., Coueffe, R., Neraudeau, D., 2009. A relative water-depth model for the Normandy Chalk (Cenomanian-Middle Coniacian, Paris Basin, France) based on facies patterns of metre-scale cycles. Sediment. Geol. 213, 1-26. doi:10.1016/j.sedgeo.2008.10.007

Li, L., Shikhov, I., Zheng, Y., Arns, C., 2014. Experiment and Simulation on NMR and Electrical Measurements on Liège Chalk. Diffus. Fundam. 22, 1-7.

Lind, I.L., 1993. Stylolites in Chalk from Leg 130 Ontong Java Plateau, in: Berger, W.H., Kroenke, J.W., Mayer, L.A. (Eds.), Proceedings of the Ocean Drilling Program, Scientific Results, Vol. 130. pp. 445-451.

Lindgreen, H., Jakobsen, F., 2012. Marine sedimentation of nano-quartz forming flint in North Sea Danian chalk. Mar. Pet. Geol. 38, 73-82. doi:10.1016/j.marpetgeo.2012.08.007 
Lindgreen, H., Jakobsen, F., Springer, N., 2010. Nano-size quartz accumulation in reservoir chalk, Ekofisk Formation, South Arne Field, North Sea. Clay Miner. 45, 171-182. doi:10.1180/claymin.2010.045.2.171

Lucia, F.J., 1995. Rock-fabric/petrophysical classification of carbonate pore space for reservoir characterization. AAPG Bull. $79,1275-1300$.

Mallon, A. J., Swarbrick, R.E., 2002. A compaction trend for non-reservoir North Sea Chalk. Mar. Pet. Geol. 19, 527-539. doi:10.1016/S0264-8172(02)00027-2

Mallon, A. J., Swarbrick, R.E., 2008. Diagenetic characteristics of low permeability, non-reservoir chalks from the Central North Sea. Mar. Pet. Geol. 25, 1097-1108. doi:10.1016/j.marpetgeo.2007.12.001

Marlière R., 1949. Le site géologique du Captage d'Hainin-Hautrage (Hainaut). Annales de la Société Géologique de Belgique, T73, B55-90.

Megawati, M., Madland, M.V., Hiorth, A., 2012. Probing pore characteristics of deformed chalk by NMR relaxation. J. Pet. Sci. Eng. 100, 123-130. doi:10.1016/j.petrol.2012.11.001

Menpes, R.J., Hillis, R.R., 1996. Determining apparent exhumation from Chalk outcrop samples, Cleveland Basin/East Midlands Shelf. Geol. Mag. 133, 751. doi:10.1017/S0016756800024596

Mimran, Y., 1975. Fabric deformation induced in Cretaceous chalks by tectonic stresses. Tectonophysics 26, 309-316. doi:http://dx.doi.org/10.1016/0040-1951(75)90097-9

Mimran, Y., 1978. The induration of Upper Cretaceous Yorkshire and Irish chalks. Sediment. Geol. 20, 141-164. doi:http://dx.doi.org/10.1016/0037-0738(78)90053-2

Minh, C.C., Petricola, M., Dennis, B., 1997. The carbonate challenge. Middle East Well Eval. Rev. 20, $36-55$.

Mitchell, S.F., 1994. New data on the biostratigraphy of the Flamborough Chalk Formation (Santonian, Upper Cretaceous) between South Landing and Danes Dyke, North Yorkshire. Proceedings of the Yorkshire Geological Society, 50, 113-8.

Mortimore, R., and Pomerol, B., 1997, Upper Cretaceous tectonic phases and end Cretaceous inversion in the Chalk of the Anglo-Paris Basin: Proceedings of the Geologist's Association, v. 108 , p. 231-255. 
Mortimore, R.N., 2011. A Chalk Revolution: what have we done to the Chalk of England? Proceedings of the Geologists' Association. 122, 232-297.

Neugebauer, J., 1974. Some aspects of cementation in chalk. Spec. Publ. Int. Assoc. Sedimentol 1, 149-176.

Neugebauer, J., 1975. Fossil-diagenese in der Schreibkreide: Coccolithen. Neues Jahrb. Geol. Paläontol. Monatsh 8, 489-502.

Nurmi, R., Standen, E., 1997. Carbonates the Inside Story. Middle East Well Eval. Rev. 26-41.

Olsen, C., Christensen, H.F., Fabricius, I.L., 2008. Static and dynamic Young's moduli of chalk from the North Sea'. Geophysics 73, E41-E50. doi:10.1190/1.2821819

Purcell, W.R., 1949. Capillary pressure - their measurements using mercury and the calculation of permeability therefrom. AIME Pet. Trans. 186, 39-48.

Regnet, J.B., Robion, P., David, C., Fortin, J., Brigaud, B., Yven, B., 2014. Accoustic and reservoir properties of microporous caronate rocks: implication of micrite particle size and morphology. Am. Geophys. Union 1-22. doi:10.1002/2014JB011313.Received

Richard, J., Sizun, J.P., Machhour, L., 2005. Environmental and diagenetic records from a new reference section for the Boreal realm: The Campanian chalk of the Mons basin (Belgium). Sediment. Geol. 178, 99-111. doi:10.1016/j.sedgeo.2005.04.001

Robaszynski, F., and Amédro, F., 1986, The Cretaceous of the Boulonnais (France) and a comparison with the Cretaceous of Kent (United Kingdom): Proceedings of the Geologist's Association, v. 97, p. 171-208.

Robaszynski F., Gale A.S., Juignet P., Amédro F. and Hardenbol J. ,1998. Sequence stratigraphy in the upper Cretaceous series of the Anglo-Paris basin : exemplified by the Cenomanian stage. SEPM Spec. Public., 60, 363-386.

Roduit, N., 2007. JMicroVision: Image analysis toolbox for measuring and quantifying components of high-definition images.

Røgen, B., Fabricius, I.L., 2002. Influence of clay and silica on permeability and capillary entry pressure of chalk reservoirs in the North Sea. Pet. Geosci. 8 , 287-293. doi:10.1144/petgeo.8.3.287 
Scholle, P., 1974. Diagenesis of Upper Cretaceous chalks from England, Northern Ireland, and the North Sea. Spec. Publ. Int. Assoc. Sedimentol 1, 177-210.

Scholle, P.A., 1977. Chalk diagenesis and its relation to petroleum exploration; oil from chalks, a modern miracle? AAPG Bull. 61, 982-1009.

Scholle, P.A., Albrechtsen, T., Tirsgaard, H., 1998. Formation and diagenesis of bedding cycles in uppermost Cretaceous chalks of the Dan Field, Danish North Sea. Sedimentology 45, 223-243. doi:10.1046/j.1365-3091.1998.0148e.x

Sing, K.S.W., Everett, D.H., Haul, R.A.W., Moscou, L., Pierotti, R.A., Rouquerol, J., Siemieniewska, T., 1985. Reporting physisorption data for gas/solid systems with special reference to the determination of surface area and porosity (Recommendations 1984). Pure Appl. Chem. 57, 603619. doi:doi: 10.1351/pac198557040603

Skalinski, M., Kenter, J.A.M., 2015. Carbonate petrophysical rock typing: integrating geological attributes and petrophysical properties while linking with dynamic behaviour. Geol. Soc. London, Spec. Publ. 406, 229-259. doi:10.1144/SP406.6

Strand, S., Hjuler, M.L., Torsvik, R., Pedersen, J.I., Madland, M. V., Austad, T., 2007. Wettability of chalk: impact of silica, clay content and mechanical properties. Pet. Geosci. 13, 69-80. doi:10.1144/1354-079305-696

Vincent, B., Fleury, M., Santerre, Y., Brigaud, B., 2011. NMR relaxation of neritic carbonates: An integrated petrophysical and petrographical approach. J. Appl. Geophys. 74, 38-58. doi:10.1016/j.jappgeo.2011.03.002

Wardlaw, N.C., Taylor, R.P., 1976. Mercury capillary pressure curves and the interpretation and pore structure and capillary behavior in reservoir rocks. Bull. Can. Pet. Geol 24, 225-262.

Weiler, H., 1957. Untersuchungen zur Frage der Kalk-Mergel-Sedimentation im Jura Schwabens, PhD thesis. University of Tübingen, Germany.

Westphal, H., Surholt, I., Kiesl, C., Thern, H., Kruspe, T., 2005. NMR measurements in carbonate rocks: problems and an approach to a solution. Pure Appl. Geophys. 162, 549-570.

Westphal, H. (2006): Limestone-marl alternations as environmental archives and the role of early diagenesis: a critical review . Int. Journal of Earth Science 95, 947-961. 
Whitham, F. (1993) The stratigraphy of the Upper Cretaceous Flamborough Chalk Formation north of the Humber, north-east England. Proceedings of the Yorkshire Geological Society, 49, 235-58.

Wray, D.S., Jeans, C.V., 2014. Chemostratigraphy and provenance of clays and other non-carbonate minerals in chalks of Campanian age (Upper Cretaceous) from Sussex, southern England. Clay Miner. 49, 327-340.

Ziegler, P.A., 1990. Geological atlas of Western and Central Europe, in: Shell International Petroleum Maatschappij B.V Geological Society of London. Elsevier, Amsterdam. p. 239. 
Figure 1: Map of the present day depth position of chalk deposits in North-West Europe and the location of the sampled outcrops with their maximum paleodepths (modified from Ziegler, 1990 and Hjuler \& Fabricius, 2009).

Figure 1: Overview of petrographical and petrophysical results for micritic chalk, grainy chalk and cemented chalk. The $\mathrm{T}_{21 \mathrm{~m}}$ of the NMR $\mathrm{T}_{2}$ distributions ranges from 37-58 ms for micritic chalk, 62-90 ms for grainy chalk, and $15-18 \mathrm{~ms}$ for cemented chalk samples. MICP pore throat radius size distributions show average pore throat size ranging from 194-310 nm for micritic chalk, 296-540 nm for grainy chalk and 113-137 nm for cemented chalk.

Figure 2: Overview of petrographical and petrophysical results for marl-seam chalk, argillaceous chalk and silicified chalk. The $\mathrm{T}_{2 \mathrm{~m}}$ of the $\mathrm{NMR} \mathrm{T}_{2}$ distributions ranges from 8-32 ms for marl-seam chalk, 3$11 \mathrm{~ms}$ for argillaceous chalk, and $17.6 \mathrm{~ms}$ for the silicified chalk sample. MICP pore throat size distributions show average pore throat size ranging from 50-213 nm for marl-seam chalk, 38-61 nm for coarse chalk and $12 \mathrm{~nm}$ for silicified chalk sample. Note that the SEM microtexture of marl-seam chalk varies widely - two extreme cases are pictured here with on the left, the microtexture of a clean uncemented chalk interval, and on the right the microtexture of a clay-rich seam.

Figure 3: Dunham textures encountered for each chalk lithotype: thin-section observation of 3 representative samples from mudstone (OF/CH01), wackestone (OF/CB06) and packestone (OF/CM02) textures.

Figure 5: 3D Computerized tomography reconstitution of OF/CB06, an argillaceous chalk sample and OF/CB13, a marl-seams chalk sample. The homogeneity of sample OF/CB06 was assessed, only few bioclasts appear in white. In sample OF/CB13, the lower density of the marl-seams is reflected by a ligther grey seams (2) in a darker matrix (1).

Figure 6: Silicified chalk (sample OF/BR01) under SEM. (A) Overview of the samples with patches of amorpheous silica. (B) Zoom on an amorphous silica zone (C) Micritic chalky matrix with some intact coccoliths, nano-aggregates of silica (D) Small quartz crystals between the grains. (E and F) BackScattered Electron SEM micrograph of a thin-section, with the darker zones being more silicified, frequently occurring as cement inside forams and calcispheres. Calcite of the shells is well preserved (white).

Figure 7: Petrophysical measurements with (A) porosity versus permeability, (B) Average PTR (Pore Throat Radius) versus permeability, (C) $\mathrm{T}_{2 \mathrm{~m}}$ versus average PTR, and (D) $\mathrm{T}_{2 \mathrm{~m}}$ versus insoluble residue displaying an exponential relationship.

Figure 8: Porecast (upper images) and rock chip (lower images) SEM pictures of micritic chalk (sample OF/CH01: A, C) and cemented chalk (sample FA39B: B, C). Porecasts from epoxy resin 
allow to vizualise the porous network, while rock samples pictures show the rock microtexture. The geometrical pore shapes of cemented chalk is highlighted by an arrow (B).

Figure 9: Grainy chalk OF/ETR33 coarse sample (A) MICP slightly bimodal pore-throat radii size distribution (B) NMR bimodal $\mathrm{T}_{2}$ distribution. Blue curves are micritic chalk distribution, used as references. (C) Thin-section observation under transmitted light with a binociular. Red arrows show the porosity related to large bioclasts. (D) Back-Scattered Electron SEM-micrograph of a thin-section showing the matrix microporosity (red arrows).

Figure 10: Marl-seam sample (sample OF/CB13): (A) Unimodal MICP signal, (B) Bimodal NMR signal with the first peak related to the matrix and the second to the intraparticle porosity (C) Epoxy resin porecast showing the narrow pores in the foram tests connecting the intraparticle porosity and the micritic matrix; (D) Thin-section observation under transmitted and fluorescence light (respectively left and right), highlighting the intraparticle porosity; (E) Back-Scattered Electron SEM-micrograph of a thin-section to vizualise the intraparticle microporosity and its connection to matrix porosity. Also note the clays (darker) dispersed in the matrix.

Figure 11: Typical NMR $\mathrm{T}_{2}$ distribution and MICP pore throat radii sizes distribution for 5 lithotypes: micritic, grainy, cemented, argillaceous and silicified chalks.

Figure 12: Schematic representation of the microtexture of (A) micritic chalk: highly porous chalk about $40 \%$ porosity. (B) Cemented chalk : authigenic calcite crystals in the matrix and calcite cement overgrowths on grains (in dark grey). Reduced porosity (about 18\%) and pore throat size (and thus also permeability). (C) Argillaceous chalk: clay flakes (in black) floating in the matrix and around micritic grains, reduce porosity (to $25 \%$ here), but mostly reduce permeability by reducing the pore throat sizes.

Figure 13: Distribution of the different chalk lithotypes on a ternary diagram of porosity type (chalknanoporosity, chalk-microporosity, chalk-mesoporosity) based on porosity versus NMR-T 2 distribution.

Figure 14: (A) $\mathrm{T}_{2}(\mathrm{~lm})^{2} \varnothing 4$ versus permeability plot providing gradients used to calculate the constant ' $a$ ' used in the SDR model (B) Relationship between NMR-estimated permeability KSDR and actual measured core permeability. 
Table 1: Geographic and stratigraphic location of the samples. References from studies which performed geological loggings on the studied outcrops are: (1) Amédro and Robaszynski, 2000 (2) Amédro and Robaszynski, 2001 (3) Boulvain and Pinguot, 2012 (4) Bristow et al., 1997 (5) Gale et al., 2005 (6) Gräfe, 1999 (7) Juignet and Breton, 1974 (8) Kennedy, 1969 (9) Lasseur et al., 2009 (10) Marlière, 1949 (11) Mitchell, 1994 (12) Mortimore and Pomerol, 1997 (13) Mortimore, 2011 (14) Robaszynski and Amédro, 1986 (15) Robaszynski et al., 1998 (16) Whithman, 1993.

\begin{tabular}{|c|c|c|c|c|c|c|c|}
\hline Chalk lithotype & $\begin{array}{l}\text { Sample } \\
\text { Name }\end{array}$ & Location & Latitude & Longitude & Stratigraphy & Formation name & References \\
\hline \multirow{6}{*}{ Micritic } & $\mathrm{OF} / \mathrm{CH} 01$ & Harmignies Quarry. BE & 50.420643 & 4.0244404 & $\begin{array}{c}\text { Middle } \\
\text { Campanian }\end{array}$ & Obourg & 3,10 \\
\hline & $\mathrm{OF} / \mathrm{CH} 02$ & Harmignies Quarry. BE & 50.420643 & 4.0244404 & $\begin{array}{c}\text { Middle } \\
\text { Campanian }\end{array}$ & Nouvelles & 3,10 \\
\hline & $\mathrm{OF} / \mathrm{CH} 04$ & Harmignies Quarry. BE & 50.420643 & 4.0244404 & $\begin{array}{c}\text { Upper } \\
\text { Campanian }\end{array}$ & Spiennes & 3,10 \\
\hline & OF/CO01 & Coquelles Quarry. Boulonnais. FR & 50.930955 & 1.774346 & Santonian & Caffier & 1,14 \\
\hline & OF/NH03 & Newhaven. Sussex. UK & 50.784762 & 0.023071 & Campanian & Newhaven & $4,8,12,13$ \\
\hline & OF/RA01 & Ramsgate. Kent. UK & 51.373740 & 1.448914 & Santonian & Seaford & $4,8,12,13$ \\
\hline \multirow{5}{*}{ Grainy } & OF/BG01 & Birling Gap. Sussex. UK & 50.744115 & 0.198285 & Turonian & New-Pit & $4,8,12,13$ \\
\hline & OF/CM02 & $\begin{array}{c}\text { Mimoyecques Quarry. Boulonnais. } \\
\text { FR }\end{array}$ & 50.852647 & 1.759135 & Turonian & Guet & 1 \\
\hline & OF/CM06 & $\begin{array}{c}\text { Mimoyecques Quarry. Boulonnais. } \\
\text { FR }\end{array}$ & 50.852647 & 1.759135 & Turonian & Guet & 1 \\
\hline & OF/ETR33 & Etretat. Upper Normandy. FR & 49.712103 & 0.205394 & Coniacian & Saint Pierre en Port & $7,9,12,15$ \\
\hline & OF/SS01 & Seven Sisters, Sussex, UK & 50.748322 & 0.187536 & Coniacian & Chalk Mudstone & $4,8,12,13$ \\
\hline \multirow{5}{*}{ Cemented } & OF/CB14 & Cap Blanc Nez. Boulonnais. FR & 50.936655 & 1.726030 & $\begin{array}{c}\text { Upper } \\
\text { Cenomanian }\end{array}$ & Escalles & $2,6,14$ \\
\hline & OF/FA15 & Flamborough Head. Yorkshire. UK & 54.103918 & -0.131857 & Santonian & Flamborough & 10,16 \\
\hline & OF/FA39B & Flamborough Head. Yorkshire. UK & 54.107806 & -0.090544 & Santonian & Flamborough & 10,16 \\
\hline & OF/FH11 & Flamborough Head. Yorkshire. UK & 54.105572 & -0.099754 & Santonian & Flamborough & 10,16 \\
\hline & OF/SC01 & $\begin{array}{l}\text { Saint Martin en Campagne. Up. } \\
\text { Normandy. FR }\end{array}$ & 49.968511 & 1.195942 & Turonian & Tilleul & $7,9,12,15$ \\
\hline \multirow{7}{*}{ Marl-seam } & OF/CB13 & Cap Blanc Nez. Boulonnais. FR & 50.936655 & 1.726030 & $\begin{array}{c}\text { Upper } \\
\text { Cenomanian }\end{array}$ & Escalles & $2,6,14$ \\
\hline & OF/CB16 & Cap Blanc Nez. Boulonnais. FR & 50.937992 & 1.729152 & Base Turonian & Grand Nez & $2,6,14$ \\
\hline & OF/EA02 & Eastbourne. Sussex. UK & 50.759582 & 0.284676 & Base Turonian & Hollywell Nodular & $\begin{array}{c}4,5,8,12 \\
13\end{array}$ \\
\hline & OF/ETR21 & Senneville. Upper Normandy. FR & 49.784092 & 0.423037 & $\begin{array}{l}\text { Middle } \\
\text { Turonian }\end{array}$ & Senneville & $7,9,12,15$ \\
\hline & OF/ETR47 & Senneville. Upper Normandy. FR & 49.784092 & 0.423037 & $\begin{array}{l}\text { Middle } \\
\text { Turonian }\end{array}$ & Senneville & $7,9,12,15$ \\
\hline & OF/SC02 & $\begin{array}{c}\text { Saint Martin en Campagne. Up. } \\
\text { Normandy. FR }\end{array}$ & 49.968511 & 1.195942 & Turonian & Tilleul & $7,9,12,15$ \\
\hline & OF/SC03 & $\begin{array}{l}\text { Saint Martin en Campagne. Up. } \\
\text { Normandy. FR }\end{array}$ & 49.968511 & 1.195942 & Turonian & Tilleul & $7,9,12,15$ \\
\hline \multirow{11}{*}{ Argillaceous } & OF/CB02 & Cap Blanc Nez. Boulonnais. FR & 50.902975 & 1.679754 & $\begin{array}{c}\text { Lower } \\
\text { Cenomanian }\end{array}$ & Strouanne & $2,6,14$ \\
\hline & OF/CB04 & Cap Blanc Nez. Boulonnais. FR & 50.907931 & 1.684760 & $\begin{array}{c}\text { Lower } \\
\text { Cenomanian }\end{array}$ & Strouanne & $2,6,14$ \\
\hline & OF/CB06 & Cap Blanc Nez. Boulonnais. FR & 50.907931 & 1.684760 & $\begin{array}{c}\text { Lower } \\
\text { Cenomanian }\end{array}$ & Strouanne & $2,6,14$ \\
\hline & OF/CB07 & Cap Blanc Nez. Boulonnais. FR & 50.910183 & 1.686753 & $\begin{array}{c}\text { Lower } \\
\text { Cenomanian }\end{array}$ & Petit Blanc-Nez & $2,6,14$ \\
\hline & OF/CB09 & Cap Blanc Nez. Boulonnais. FR & 50.926157 & 1.707652 & $\begin{array}{c}\text { Mid } \\
\text { Cenomanian }\end{array}$ & Petit Blanc-Nez & $2,6,14$ \\
\hline & OF/CB10 & Cap Blanc Nez. Boulonnais. FR & 50.926157 & 1.707652 & $\begin{array}{c}\text { Mid } \\
\text { Cenomanian }\end{array}$ & Petit Blanc-Nez & $2,6,14$ \\
\hline & OF/CB11 & Cap Blanc Nez. Boulonnais. FR & 50.926157 & 1.707652 & $\begin{array}{c}\text { Mid } \\
\text { Cenomanian }\end{array}$ & Cran & $2,6,14$ \\
\hline & OF/CB23 & Cap Blanc Nez. Boulonnais. FR & 50.911766 & 1.688472 & $\begin{array}{c}\text { Lower } \\
\text { Cenomanian }\end{array}$ & Petit Blanc-Nez & $2,6,14$ \\
\hline & OF/CB24 & Cap Blanc Nez. Boulonnais. FR & 50.911766 & 1.688472 & $\begin{array}{c}\text { Lower } \\
\text { Cenomanian }\end{array}$ & Petit Blanc-Nez & $2,6,14$ \\
\hline & OF/CB25 & Cap Blanc Nez. Boulonnais. FR & 50.911766 & 1.688472 & $\begin{array}{c}\text { Lower } \\
\text { Cenomanian }\end{array}$ & Petit Blanc-Nez & $2,6,14$ \\
\hline & OF/EA01 & Eastbourne. Sussex. UK & 50.759582 & 0.284676 & Cenomanian & Zig-Zag & $\begin{array}{c}4,5,8,12 \\
13\end{array}$ \\
\hline Silicified & OF/BR01 & Bruneval. Upper Normandy. FR & 49.637 .650 & 0.148597 & Cenomanian & Glauconieuse & $7,9,12,15$ \\
\hline
\end{tabular}


Table 2: Petrographic characteristics of the 35 chalk samples

\begin{tabular}{|c|c|c|c|c|c|c|}
\hline $\begin{array}{l}\text { Chalk } \\
\text { lithotype }\end{array}$ & $\begin{array}{l}\text { Sample } \\
\text { Name }\end{array}$ & Macroscopic facies & $\begin{array}{l}\text { Grain } \\
\mathrm{s}(\%)\end{array}$ & Microscopic facies & $\begin{array}{l}\text { Insoluble } \\
\text { Residue } \\
(\%)\end{array}$ & $\begin{array}{l}\text { Diagenesis } \\
\text { Index (a.u.) }\end{array}$ \\
\hline \multirow{6}{*}{ Micritic } & $\mathrm{OF} / \mathrm{CH} 01$ & Chalk Mudstone & 1.9 & Forams-rich mudstone & 0.8 & 1 \\
\hline & $\mathrm{OF} / \mathrm{CH} 02$ & Chalk Mudstone & 1.6 & Forams-rich mudstone & 0.6 & 0.5 \\
\hline & $\mathrm{OF} / \mathrm{CHO} 4$ & Chalk Mudstone & 2.1 & Forams-rich mudstone & 0.8 & 0.5 \\
\hline & $\mathrm{OF} / \mathrm{CO} 01$ & Chalk Mudstone & 6 & Forams-rich mudstone & 0.9 & 1 \\
\hline & $\mathrm{OF} / \mathrm{NH} 03$ & Massive Chalk Mudstone & - & - & 0.7 & 2.5 \\
\hline & OF/RA01 & Chalk Mudstone & - & - & 0.8 & 1.5 \\
\hline \multirow{5}{*}{ Grainy } & OF/BG01 & Massive Chalk Mudstone & - & - & 0.4 & 1 \\
\hline & OF/CM02 & Massive Chalk Mudstone & 40.1 & Bioclastic forams-rich packstone & 1.8 & 1 \\
\hline & OF/CM06 & Massive Chalk Mudstone & 32.5 & Bioclastic forams-rich packstone & 0.9 & 1 \\
\hline & OF/ETR33 & Chalk Grainstone & 42.8 & Bioclastic packstone & 0.3 & 2 \\
\hline & OF/SS01 & Massive Chalk Mudstone & - & - & 0.5 & 1.5 \\
\hline \multirow{5}{*}{ Cemented } & OF/CB14 & Massive Chalk Mudstone & 8.3 & Calcisphere-rich mudstone & 5.9 & 6.5 \\
\hline & OF/FA15 & Massive Chalk Mudstone & 4.6 & Calcisphere-rich mudstone & 3.3 & 7 \\
\hline & OF/FA39B & Massive Veined Chalk Mudstone & 5.7 & Calcisphere-rich mudstone & 3.5 & 7.5 \\
\hline & OF/FH11 & Massive Chalk Mudstone & 5.4 & Calcisphere-rich mudstone & 3.2 & 6.5 \\
\hline & OF/SC01 & Laminated Chalk Mudstone & - & - & 4.3 & 6 \\
\hline \multirow{7}{*}{ Marl-seam } & OF/CB13 & $\begin{array}{l}\text { Burrowed Laminated Argillaceous Chalk } \\
\text { Mudstone }\end{array}$ & 6.3 & $\begin{array}{l}\text { Forams and sponge spicule-rich } \\
\text { mudstone }\end{array}$ & 14.3 & 3 \\
\hline & OF/CB16 & Pebbly Argillaceous Chalk Mudstone & & Nodular- bioclastic wackestone & 7.6 & 4.5 \\
\hline & OF/EA02 & Pebbly Argillaceous Chalk Mudstone & 14.1 & Nodular- Calcisphere-rich wackestone & 5.7 & 5 \\
\hline & OF/ETR21 & Finely Laminated Chalk Mudstone & 7.6 & Bioclasts and forams-rich mudstone & 3.8 & 1 \\
\hline & OF/ETR47 & $\begin{array}{l}\text { Burrowed Laminated Argillaceous Chalk } \\
\text { Mudstone }\end{array}$ & 16.3 & Bioclasts and forams-rich wackestone & 2.7 & 1.5 \\
\hline & OF/SC02 & $\begin{array}{l}\text { Burrowed Laminated Argillaceous Chalk } \\
\text { Mudstone }\end{array}$ & 12 & Nodular mudstone & 5.7 & 3.5 \\
\hline & OF/SC03 & Massive Chalk Mudstone & - & - & 5.4 & 3 \\
\hline \multirow{11}{*}{ Argillaceous } & OF/CB02 & Glauconitic Chalk & 7.7 & Bioclastic mudstone & 24.9 & 3 \\
\hline & OF/CB04 & Argillaceous Massive Chalk Mudstone & 12.8 & $\begin{array}{l}\text { Bioclasts and calcisphere-rich } \\
\text { wackestone }\end{array}$ & 20.8 & 4 \\
\hline & OF/CB06 & Argillaceous Chalk Mudstone & 16.5 & Bioclastic wackestone & 23.0 & 3.5 \\
\hline & OF/CB07 & Massive Chalk Mudstone & 7.9 & Calcisphere-rich mudstone & 17.5 & 5.5 \\
\hline & OF/CB09 & $\begin{array}{l}\text { Burrowed Massive Argillaceous Chalk } \\
\text { Mudstone }\end{array}$ & 11.4 & Bioclastic wackestone & 26.2 & 4 \\
\hline & OF/CB10 & Burrowed Massive Chalk Mudstone & 12.9 & Calcisphere-rich wackestone & 9.7 & 6 \\
\hline & OF/CB11 & Burrowed Argillaceous Chalk Mudstone & 17.2 & Bioclastic and forams-rich wackestone & 29.0 & 3.5 \\
\hline & OF/CB23 & Argillaceous Chalk Mudstone & - & - & 17.8 & 5 \\
\hline & OF/CB24 & Massive Argillaceous chalk Mudstone & - & - & 27.0 & 3.5 \\
\hline & OF/CB25 & Massive Argillaceous chalk Mudstone & - & - & 22.0 & 4 \\
\hline & OF/EA01 & $\begin{array}{l}\text { Burrowed Massive Argillaceous Chalk } \\
\text { Mudstone }\end{array}$ & 13.6 & Calcisphere-rich wackestone & 9.8 & 5 \\
\hline Silicified & OF/BR01 & Silicified Chalk & - & Silicified mudstone & 76.8 & 8 \\
\hline
\end{tabular}




\section{ACCEPTED MANUSCRIPT}

Table 3: Petrophysical results on the 35 selected chalk samples

\begin{tabular}{|c|c|c|c|c|c|c|c|}
\hline Chalk lithotype & Samples Name & $\begin{array}{c}\text { Ambient } \\
\text { Porosity } \\
(\%)\end{array}$ & $\begin{array}{l}\text { Klinkenberg } \\
\text { Permeability } \\
(\mathrm{mD})\end{array}$ & $\begin{array}{l}\text { Grain } \\
\text { density } \\
\left(\mathrm{g} / \mathrm{cm}^{3}\right)\end{array}$ & $\begin{array}{l}T_{21 \mathrm{~m}} \\
(\mathrm{~ms})\end{array}$ & $\begin{array}{l}\text { Average } \\
\text { Pore throat } \\
\text { radius } \\
(\mathrm{nm})\end{array}$ & $\begin{array}{l}\text { Specific } \\
\text { surface area } \\
\left(\mathrm{m}^{2} / \mathrm{g}\right)\end{array}$ \\
\hline \multirow{6}{*}{ Micritic } & $\mathrm{OF} / \mathrm{CH} 01$ & 41.9 & 3.18 & 2.70 & 57.8 & 249 & 2.17 \\
\hline & $\mathrm{OF} / \mathrm{CH} 02$ & 44.6 & 4.48 & 2.71 & 44.1 & 270 & 2.2 \\
\hline & $\mathrm{OF} / \mathrm{CH} 04$ & 42.4 & 2.85 & 2.71 & 37.5 & 194 & - \\
\hline & OF/CO01 & 42.9 & 5.83 & 2.70 & 50.7 & - & - \\
\hline & OF/NH03 & 28.5 & 1.84 & 2.71 & 45.0 & - & - \\
\hline & OF/RA01 & 45.9 & 5.95 & 2.70 & 47.3 & 310 & - \\
\hline \multirow{5}{*}{ Grainy } & OF/BG01 & 37.8 & 3.09 & 2.68 & 90.0 & - & \\
\hline & OF/CM02 & 39.7 & 3.67 & 2.70 & 62.9 & 302 & \\
\hline & OF/CM06 & 43.6 & 4.32 & 2.71 & 86.2 & - & - \\
\hline & OF/ETR33 & 33.8 & 13.30 & 2.70 & 88.2 & 540 & 0.8 \\
\hline & OF/SS01 & 40.2 & 3.10 & 2.68 & 80.5 & 296 & - \\
\hline \multirow{5}{*}{ Cemented } & OF/CB14 & 27.1 & 0.43 & 2.70 & 16.2 & 13 & 2.7 \\
\hline & OF/FA15 & 17.6 & 0.10 & 2.71 & 15.3 & & - \\
\hline & OF/FA39 & 16.2 & 0.14 & 2.71 & 15.7 & 114 & 1.9 \\
\hline & OF/FA11 & 19.3 & 0.16 & 2.71 & 16.3 & - & - \\
\hline & OF/SC01 & 23.8 & 0.44 & 2.70 & 17.4 & 137 & - \\
\hline \multirow{7}{*}{ Marl-seam } & OF/CB13 & 31.4 & 0.30 & 2.68 & 8.6 & 61 & 8.6 \\
\hline & OF/CB16 & 20.7 & 0.19 & 2.71 & 12.0 & - & 9 \\
\hline & OF/EA02 & 14.5 & 0.25 & 2.70 & 3.9 & 50 & - \\
\hline & OF/ETR21 & 36.4 & 1.32 & 2.70 & 31.7 & 213 & - \\
\hline & OF/ETR47 & 40.4 & 2.68 & 2.68 & 29.9 & - & - \\
\hline & OF/SC02 & 33.0 & 0.48 & 2.68 & 10.4 & 103 & - \\
\hline & OF/SC03 & 25.4 & 0.40 & 2.69 & 21.0 & - & - \\
\hline \multirow{11}{*}{ Argillaceous } & OF/CB02 & 21.6 & 0.10 & 2.69 & 3.5 & 43 & - \\
\hline & OF/CB04 & 18.8 & 0.06 & 2.69 & 3.6 & - & - \\
\hline & OF/CB06 & 23.4 & 0.11 & 2.68 & 4.3 & 54 & - \\
\hline & OF/CB07 & 21.4 & 0.13 & 2.70 & 10.3 & - & - \\
\hline & OF/CB09 & 22.1 & 0.08 & 2.68 & 5.1 & 48 & - \\
\hline & OF/CB10 & 18.9 & 0.10 & 2.70 & 5.9 & 61 & - \\
\hline & OF/CB11 & 23.8 & 0.10 & 2.69 & 7.0 & 38 & 11.23 \\
\hline & OF/CB23 & 21.0 & 0.06 & 2.68 & 4.0 & - & - \\
\hline & OF/CB24 & 18.2 & 0.08 & 2.67 & 5.7 & - & - \\
\hline & OF/CB25 & 20.1 & 0.06 & 2.69 & 4.9 & - & - \\
\hline & OF/EA01 & 14.2 & 0.06 & 2.72 & 3.6 & 113 & - \\
\hline Silicified & OF/BR01 & 26.4 & 0.04 & 2.45 & 17.6 & 12 & - \\
\hline
\end{tabular}



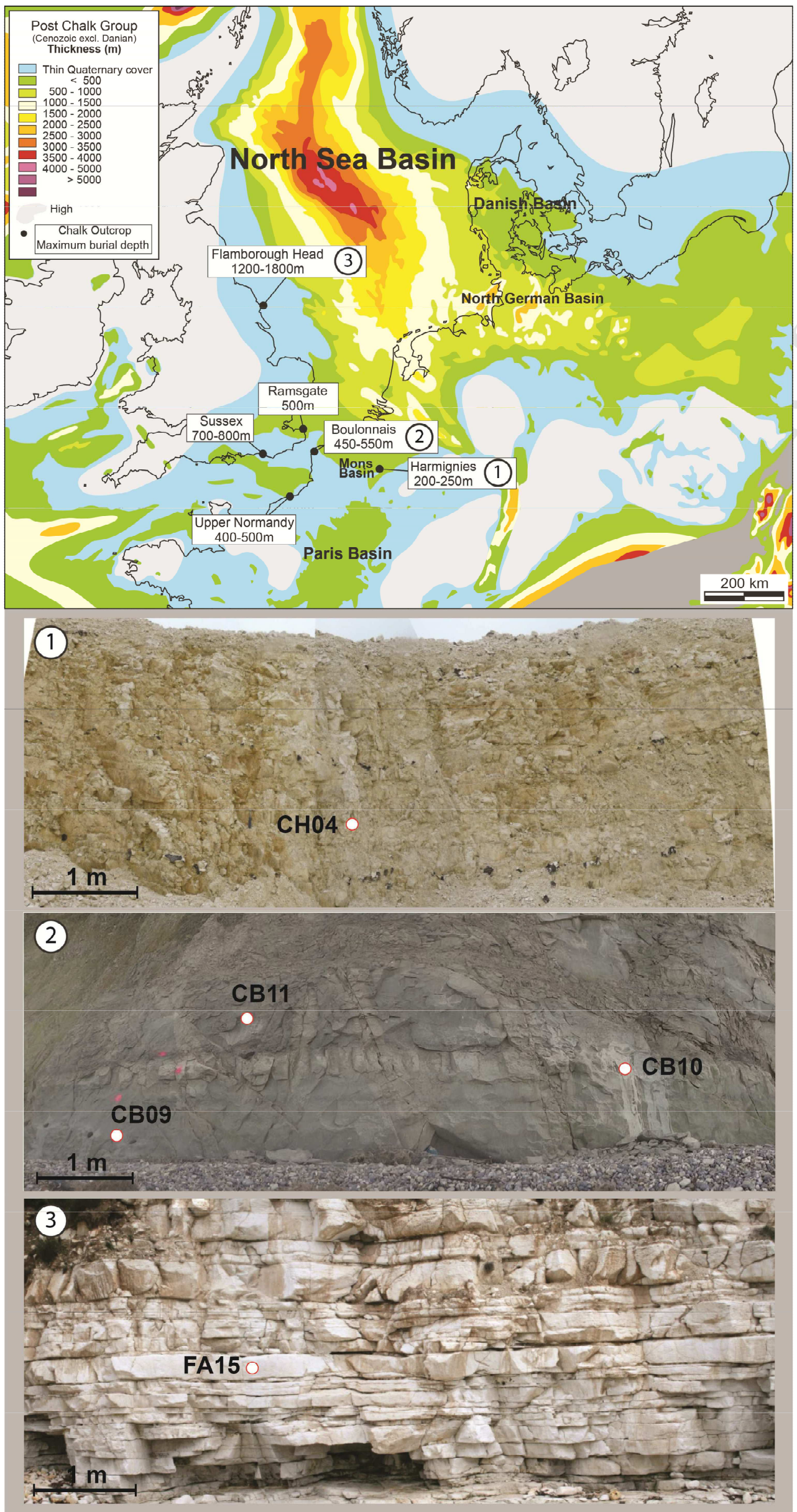

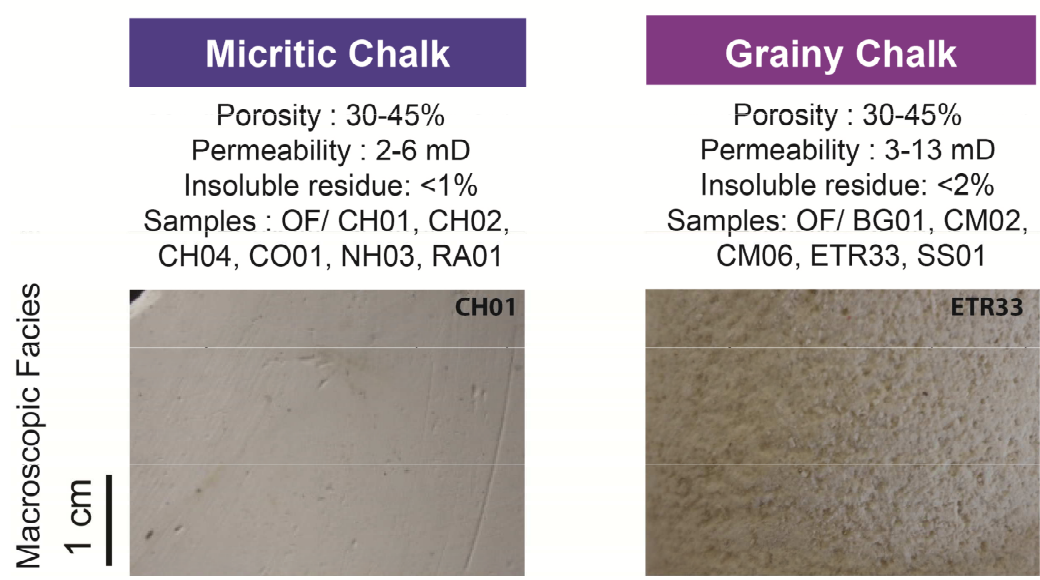

\section{Cemented Chalk}

Porosity : $16-27 \%$

Permeability : 0.1-0.4 mD Insoluble residue: $4-5 \%$

Samples: OF/ CB14, FA15,

FA39B, FH11, SC01
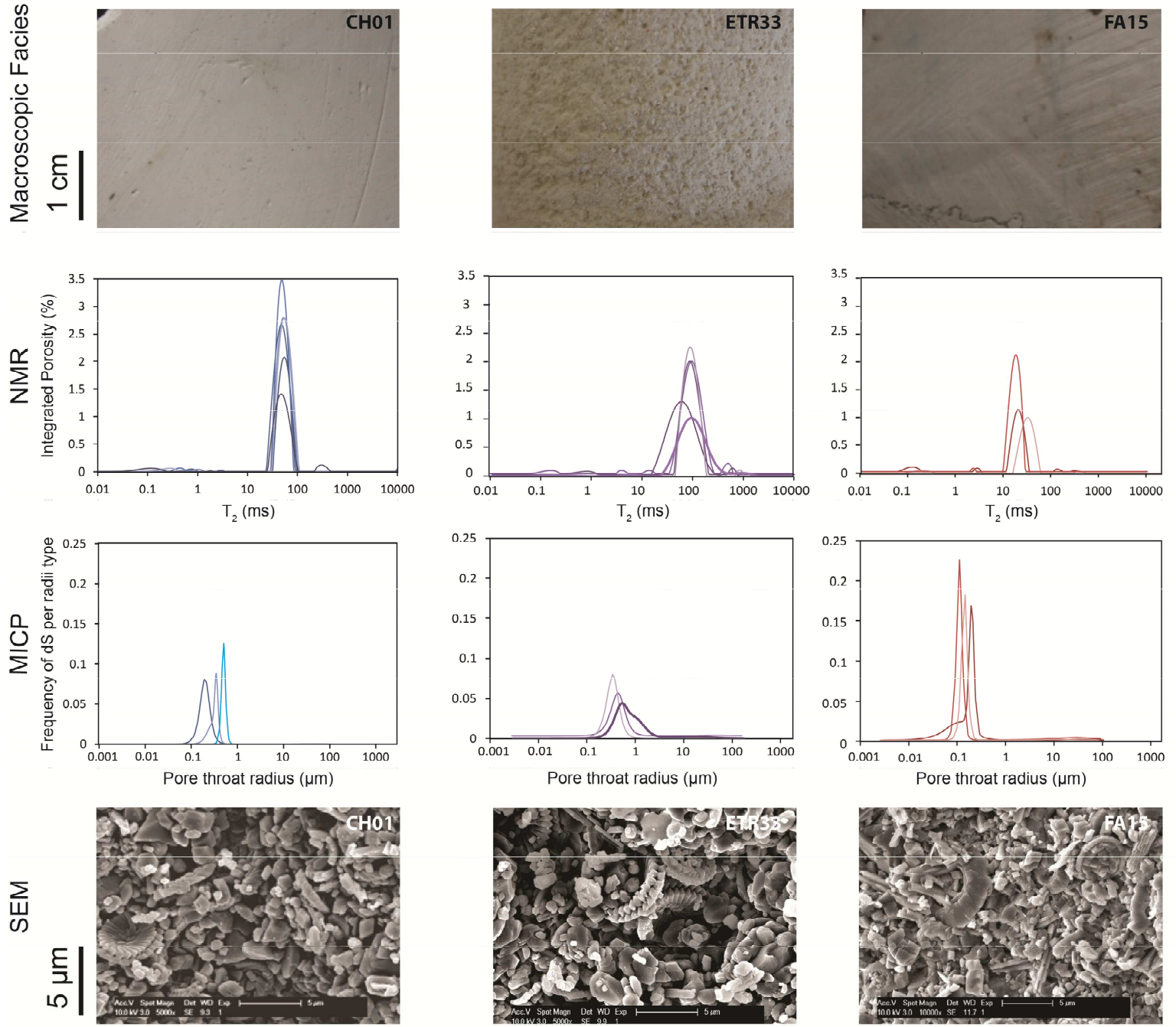


\section{Marl-seam Chalk}

Porosity : $14-40 \%$

Permeability : 0.19-2.7 mD

Insoluble residue: $2-15 \%$

Samples: OF/ CB13, CB16, EA02, ETR21, ETR47, SC02, SC03
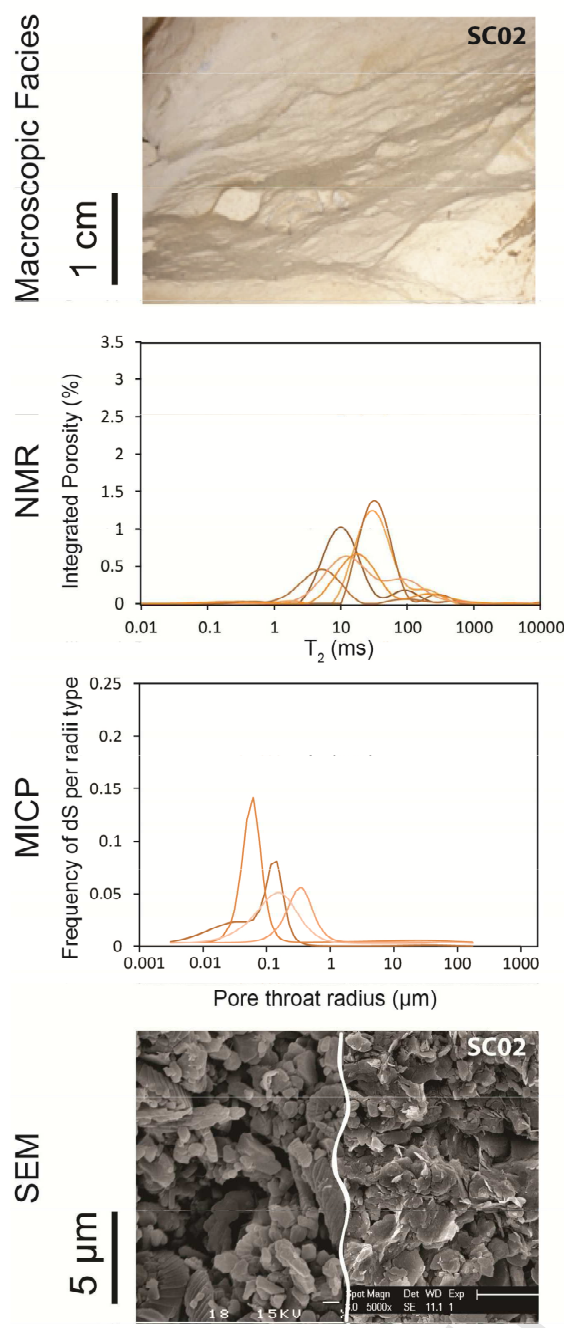

Argillaceous Chalk Porosity : $14-24 \%$

Permeability : $0.06-0.11 \mathrm{mD}$

Insoluble residue: $10-29 \%$

Samples: OF/ CB02, CB04, CB06, CB07, CB09, CB10, CB11, CB23, CB24, CB25, EA01
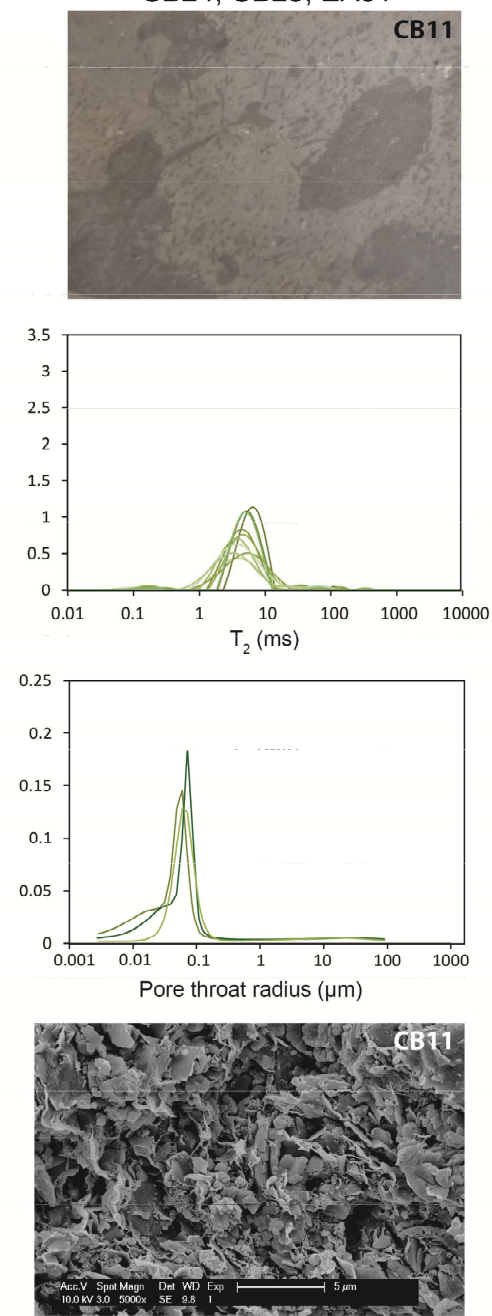

\section{Silicified Chalk}

Porosity : $24 \%$

Permeability : $0.04 \mathrm{mD}$

Insoluble residue: $76 \%$

Sample: OF/SBR01
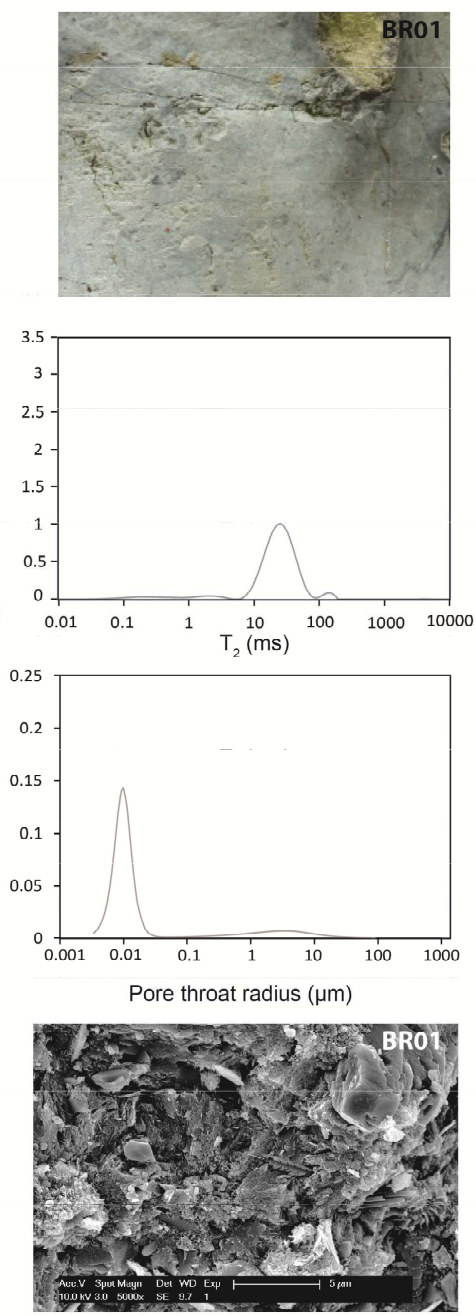


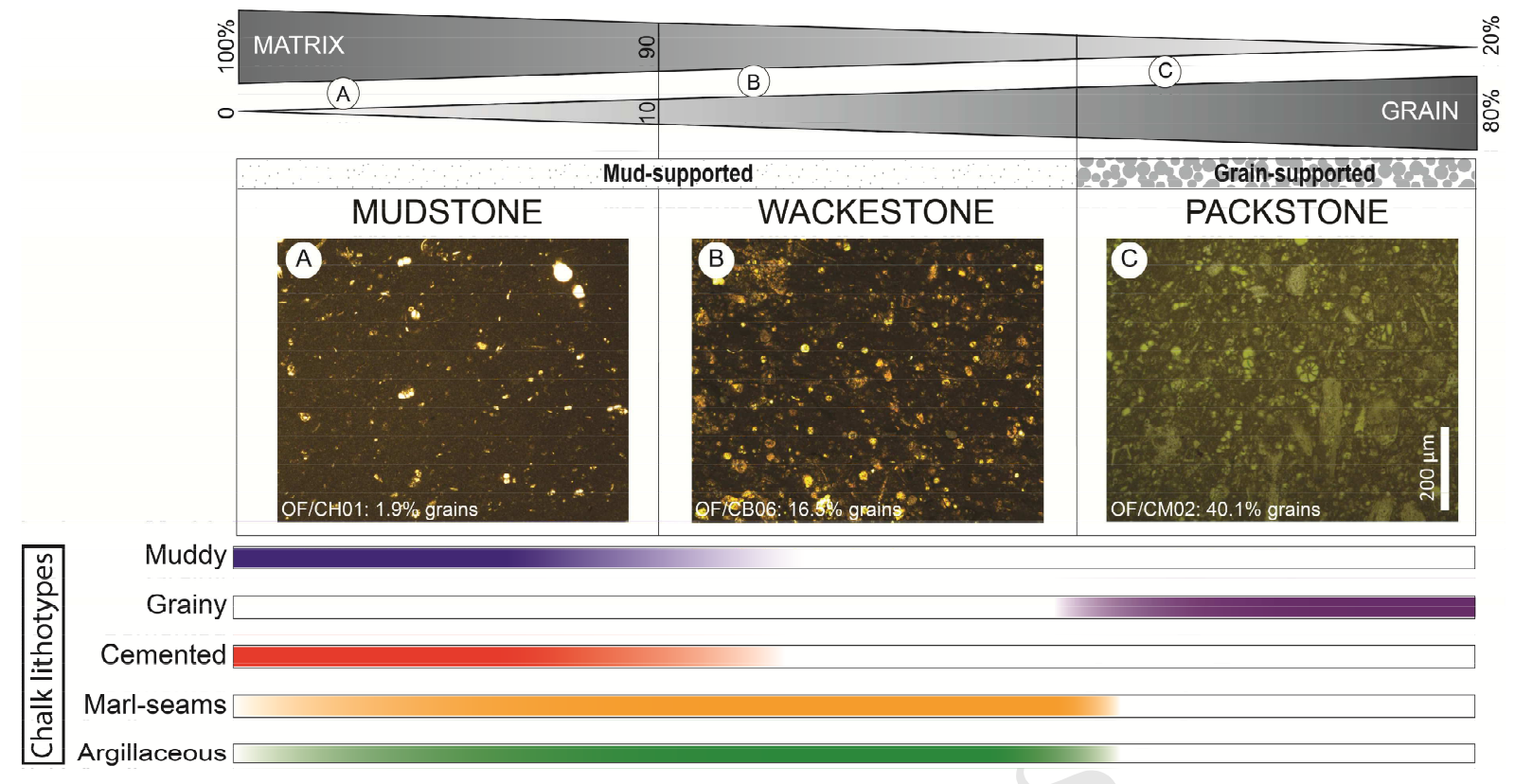



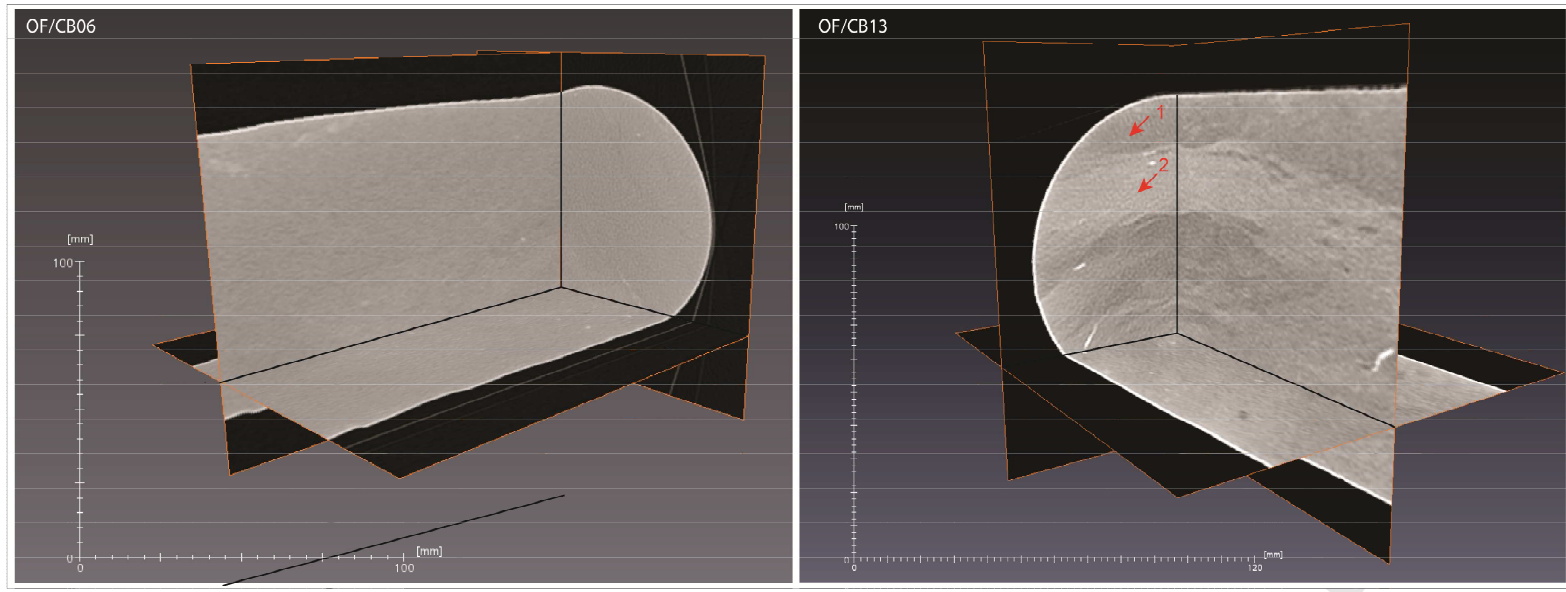


\section{ACCEPTED MANUSCRIPT}
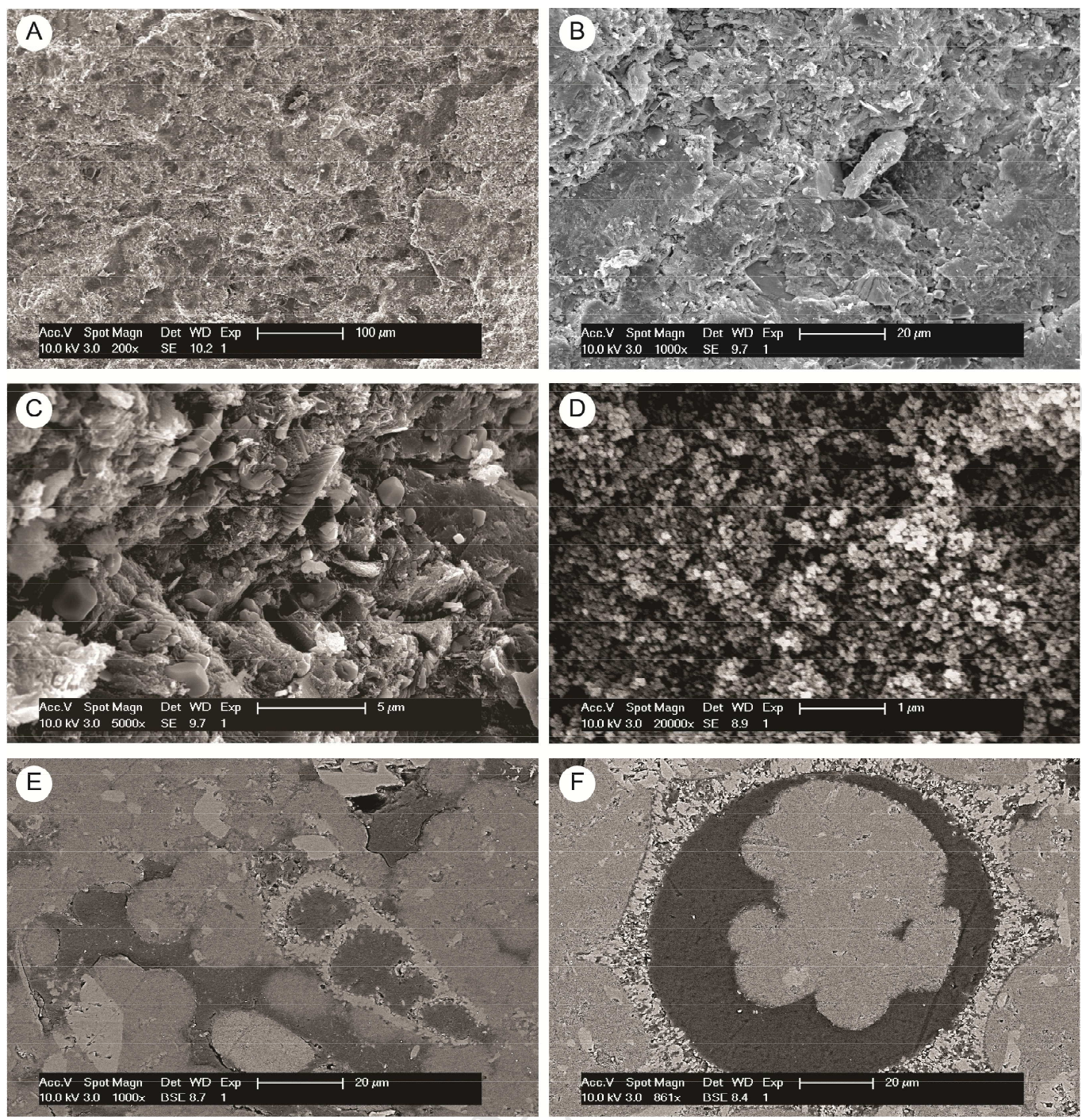

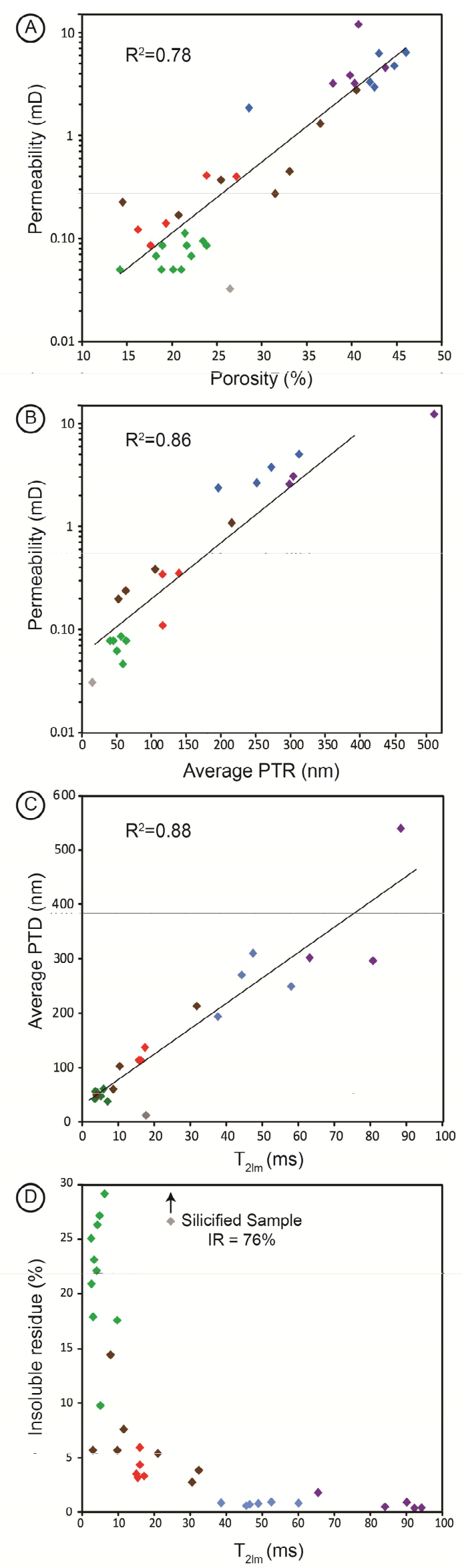

- Micritic chalk $\quad$ Cemented chalk $*$ Argillaceous chalk
- Grainy chalk $\quad$ Marl-seams chalk Silicified chalk 

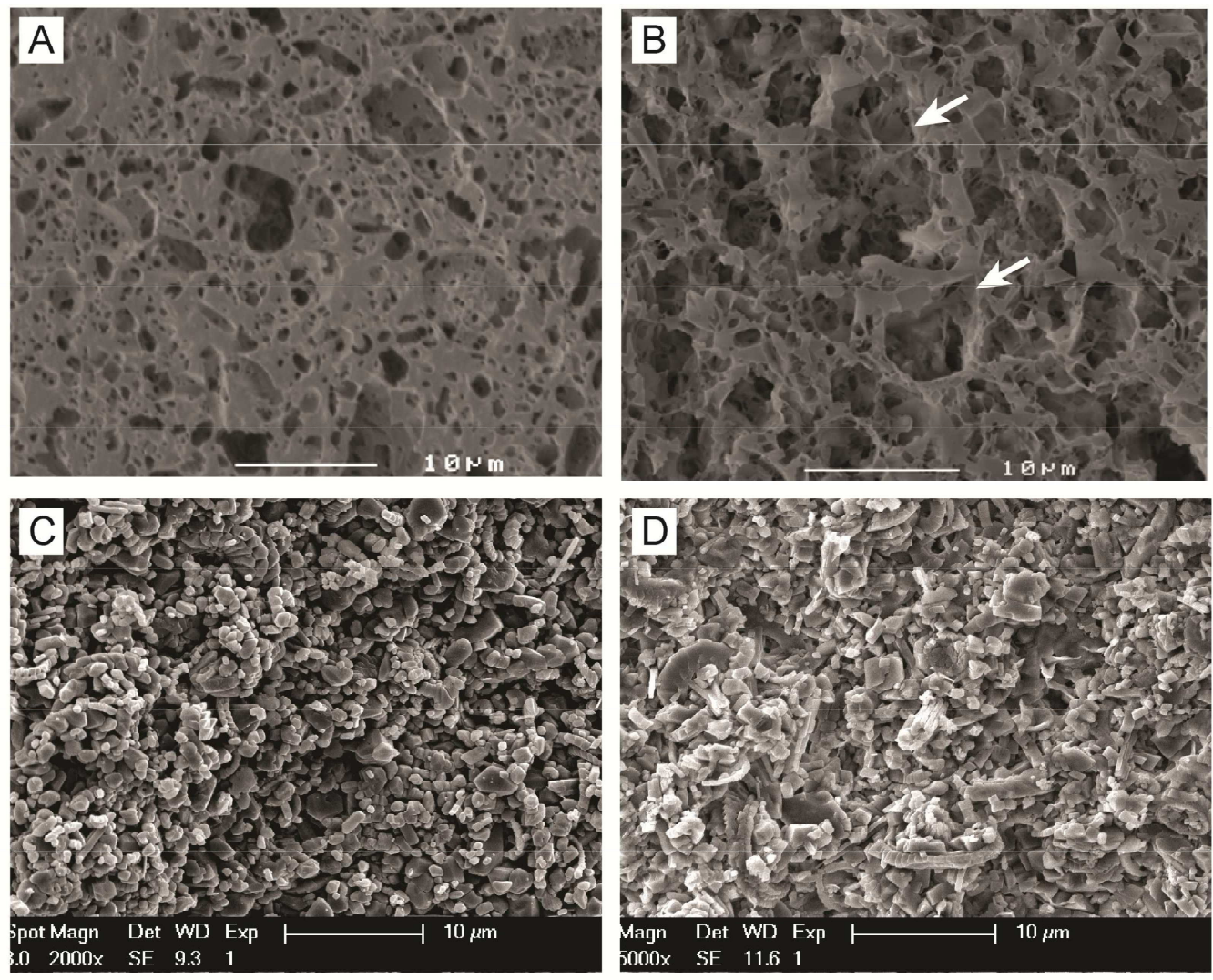

.000x SE 11.61 

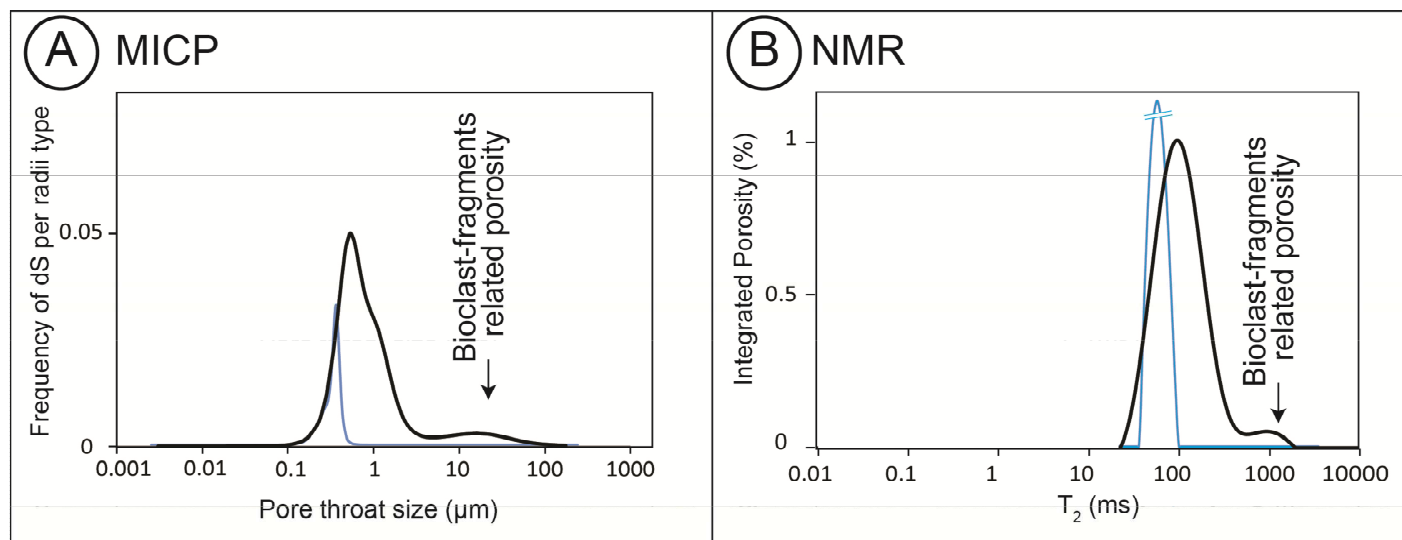

\section{(C) Binocular transmitted light}

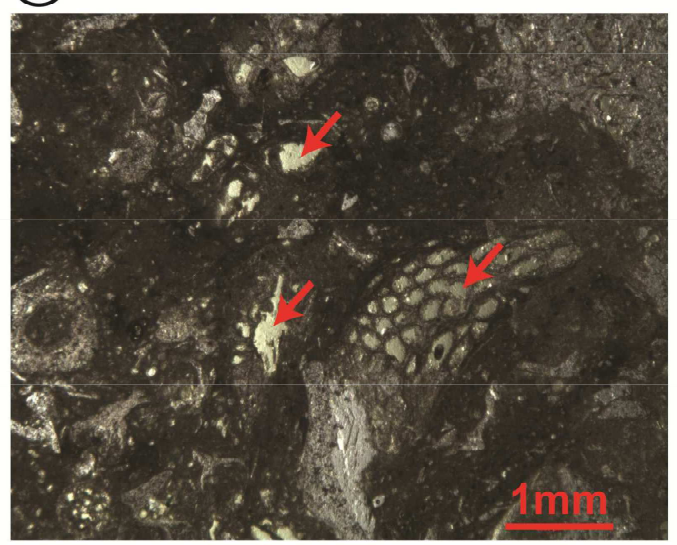

(D) SEM-BSE

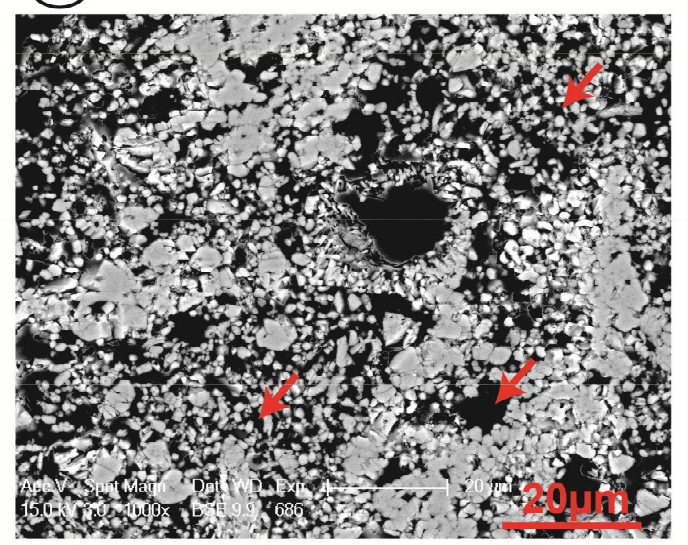



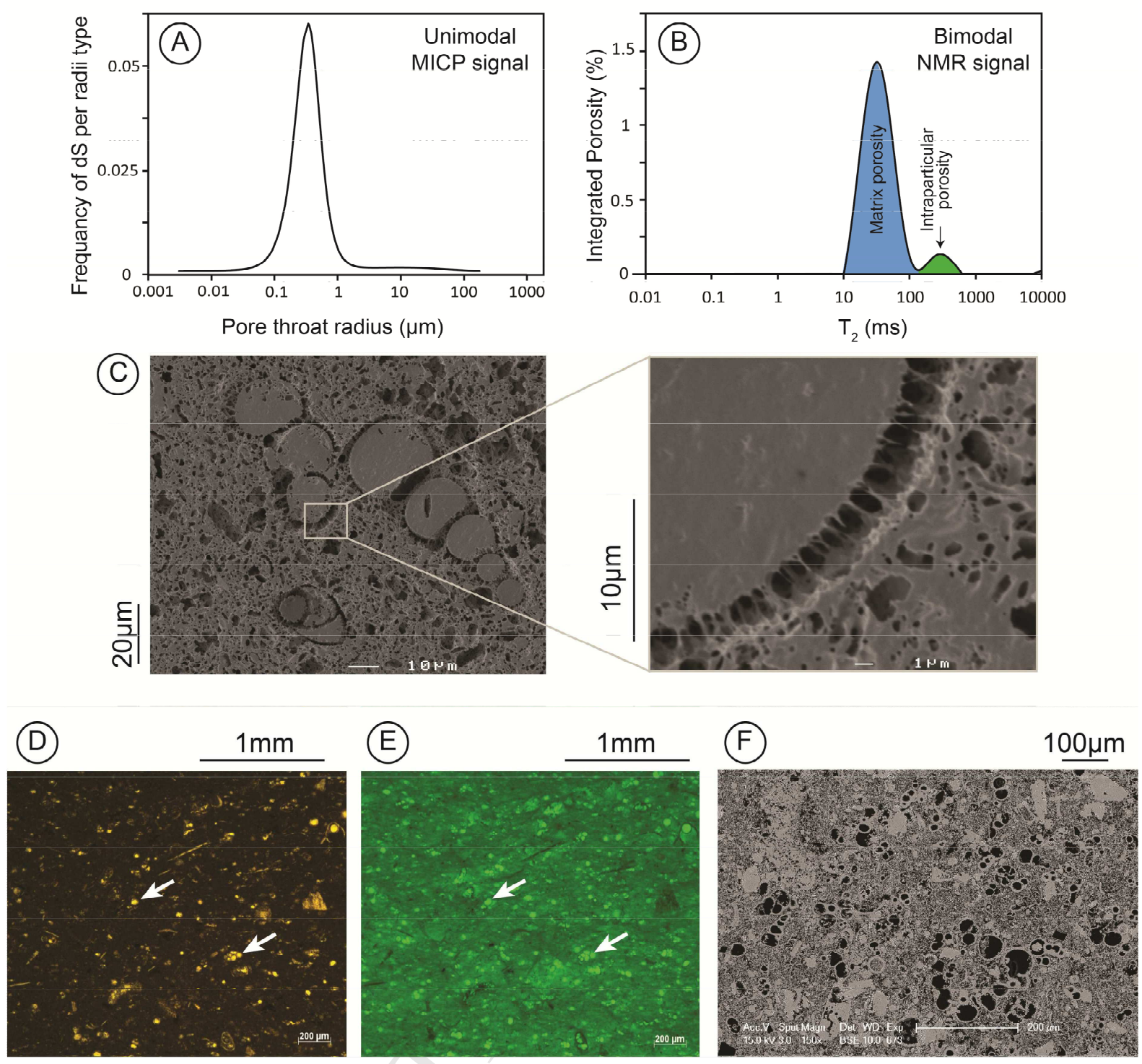

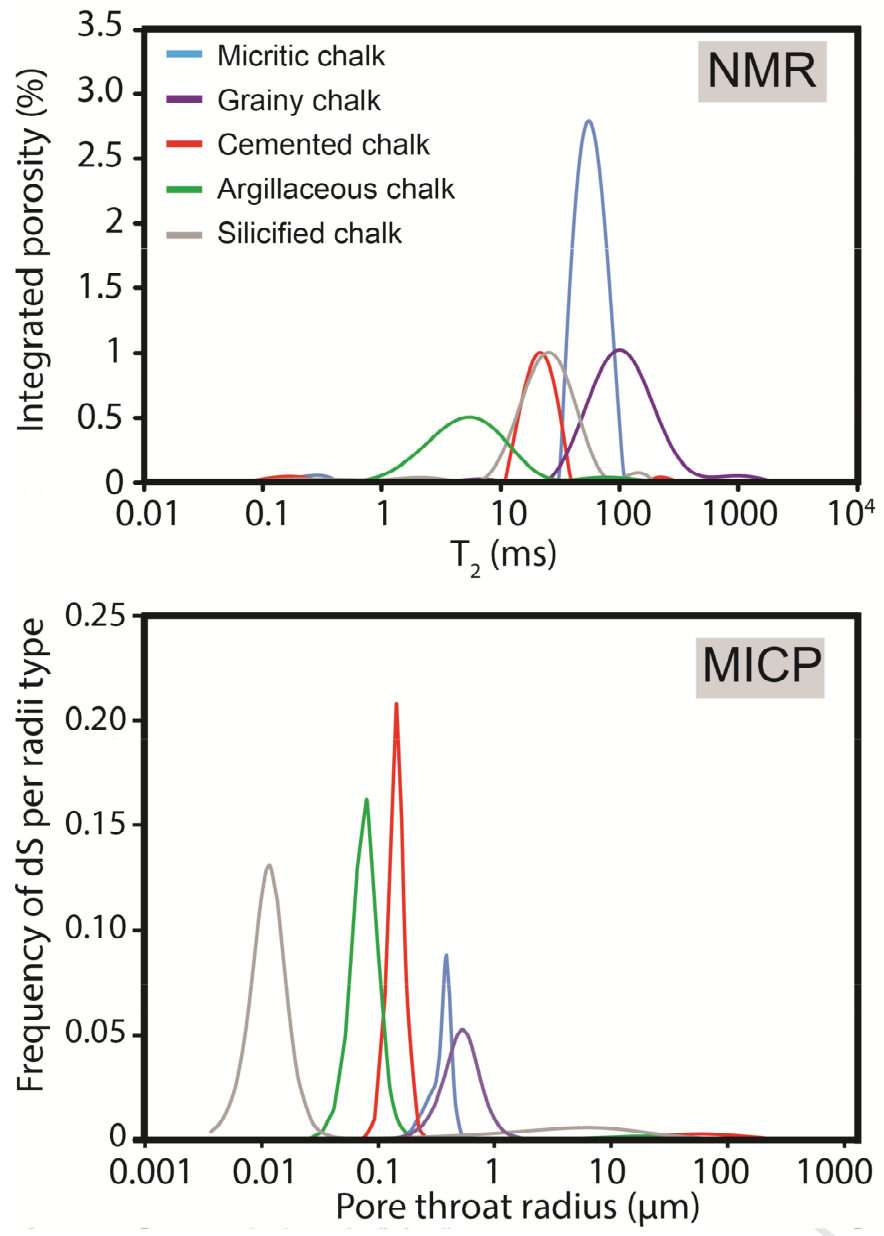

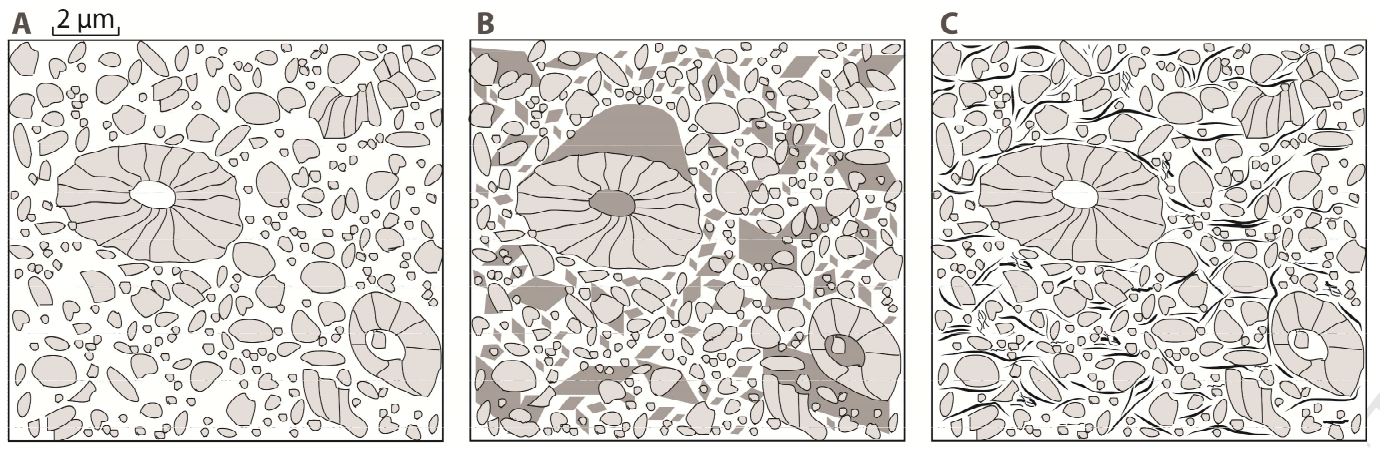


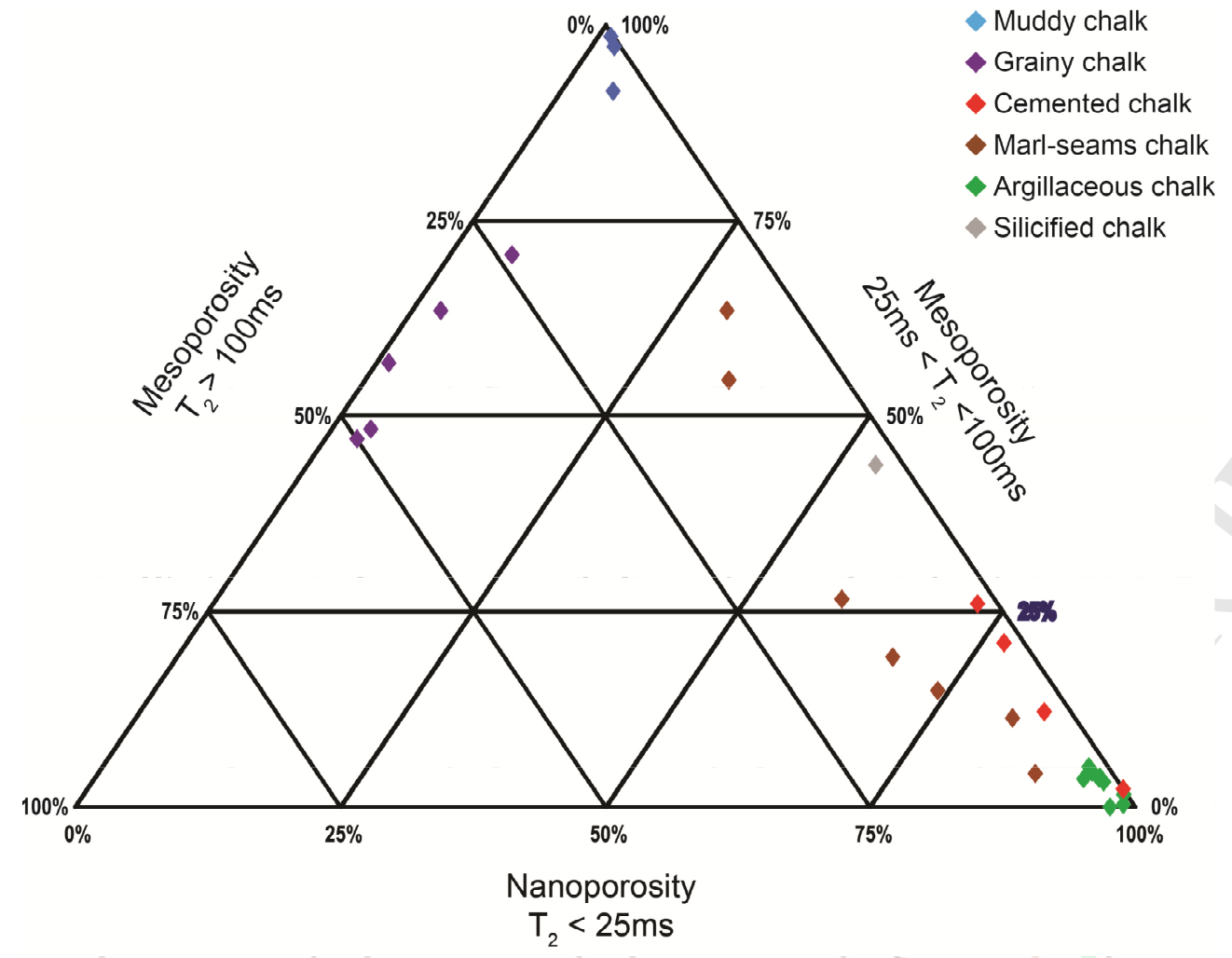



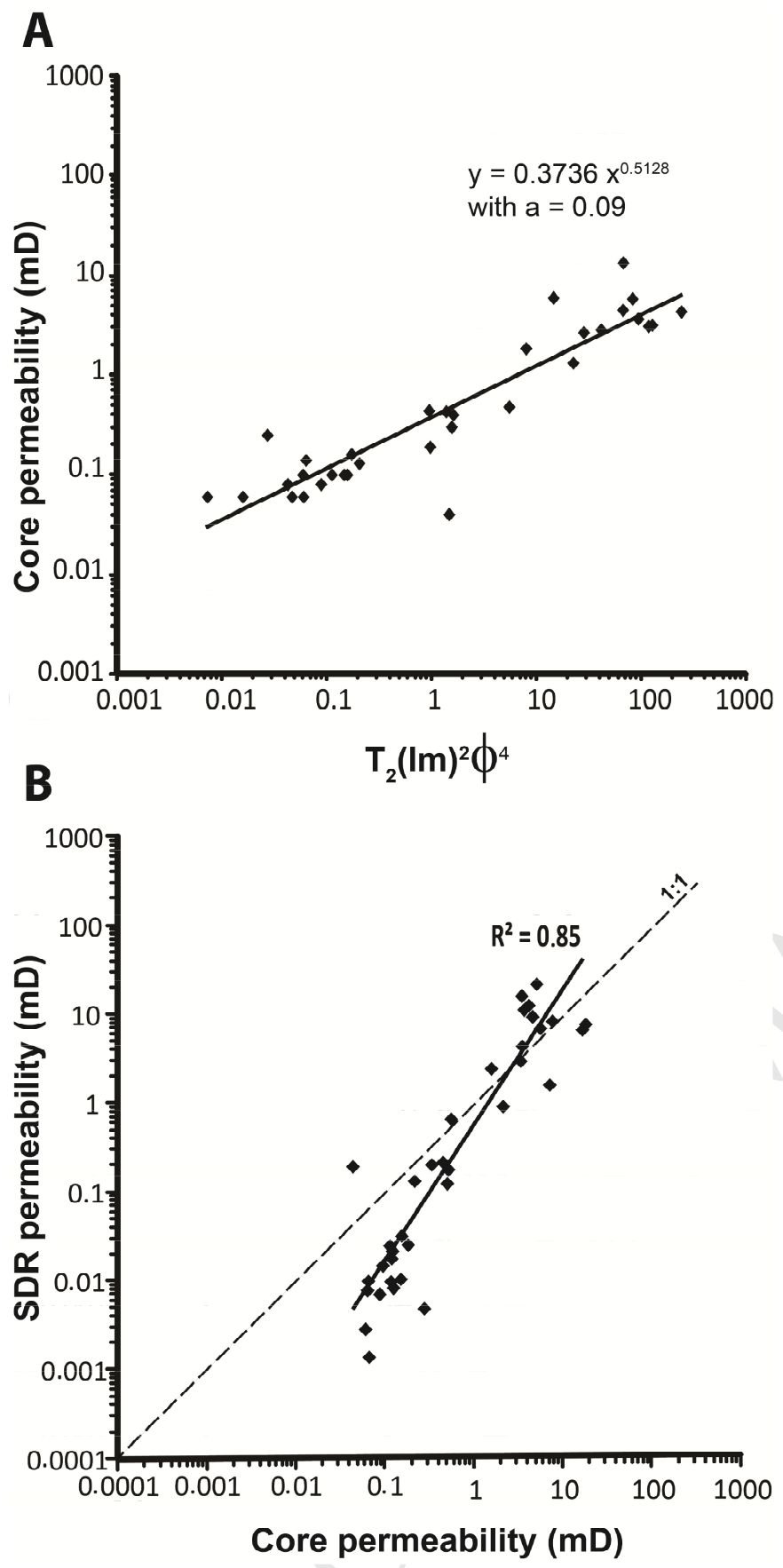


\section{Highlights}

- Low-field NMR $\mathrm{T}_{2}$ distributions allow to differentiate 5 chalk lithotypes

- Each lithotype displays distinct petrographical and petrophysical properties

- Main permeability-reducing factors in chalks: non-carbonate content and cements

- Bimodal NMR signal of marl-seams is related to intraparticle porosity preservation

- Permeability can be inferred from NMR measurements using the SDR model 